\title{
Coordination Chemistry of 4-Methyl-2,6,7-trioxa-1- phosphabicyclo[2,2,1]heptane: Preparation and Characterization of Ru(II) Complexes
}

\author{
Evan E. Joslin, Claire L. McMullin, T. Brent Gunnoe, ${ }^{*}$ Thomas R. Cundari, ${ }^{*}$ Michal Sabat,
} and William H. Myers

\begin{abstract}
Department of Chemistry, University of Virginia, Charlottesville, Virginia 22904, United States
Center for Advanced Scientific Computing and Modeling (CASCaM), University of North Texas, Denton, Texas 76203, United States

Nanoscale Materials Characterization Facility, Department of Materials Science and Engineering, University of Virginia, Charlottesville, Virginia 22904, United States

Department of Chemistry, University of Richmond, Richmond, Virginia 23173, United States
\end{abstract}

Supporting Information

ABSTRACT: The complexes TpRu[P $\left(\mathrm{OCH}_{2}\right)_{2}\left(\mathrm{OCCH}_{3}\right]$ $\left(\mathrm{PPh}_{3}\right) \mathrm{Cl}$ (2) $[\mathrm{Tp}=$ hydridotris (pyrazolyl)borate; $\mathrm{P}$ $\left(\mathrm{OCH}_{2}\right)_{2}\left(\mathrm{OCCH}_{3}\right)$ (1) = (4-methyl-2,6,7-trioxa-1phosphabicyclo $[2,2,1]$ heptane $]$ and $\mathrm{TpRu}(\mathrm{L})\left(\mathrm{PPh}_{3}\right) \mathrm{Cl}[\mathrm{L}=$ $\mathrm{P}\left(\mathrm{OCH}_{2}\right)_{3} \mathrm{CEt}$ (3), $\mathrm{PMe}_{3}$ (4) or $\left.\mathrm{P}(\mathrm{OMe})_{3}(5)\right],\left(\eta^{6}\right.$ $\left.\mathrm{C}_{6} \mathrm{H}_{6}\right) \mathrm{Ru}(\mathrm{L}) \mathrm{Cl}_{2}\left[\mathrm{~L}=\mathrm{PPh}_{3}(6), \mathrm{P}(\mathrm{OMe})_{3}(7), \mathrm{PMe}_{3}\right.$ (8), $\mathrm{P}\left(\mathrm{OCH}_{2}\right)_{3} \mathrm{CEt}(9)$, $\mathrm{CO}(10)$ or $\left.\mathrm{P}\left(\mathrm{OCH}_{2}\right)_{2}\left(\mathrm{OCCH}_{3}\right)(11)\right]$ and $\left(\eta^{6}-p\right.$-cymene $) \mathrm{Ru}(\mathrm{L}) \mathrm{Cl}_{2}\left[\mathrm{~L}=\mathrm{P}\left(\mathrm{OCH}_{2}\right)_{3} \mathrm{CEt}(12)\right.$, $\mathrm{P}\left(\mathrm{OCH}_{2}\right)_{2}\left(\mathrm{OCCH}_{3}\right) \mathrm{P}\left(\mathrm{OCH}_{2}\right)_{2}\left(\mathrm{OCCH}_{3}\right)$ (13), $\mathrm{P}(\mathrm{OMe})_{3}$
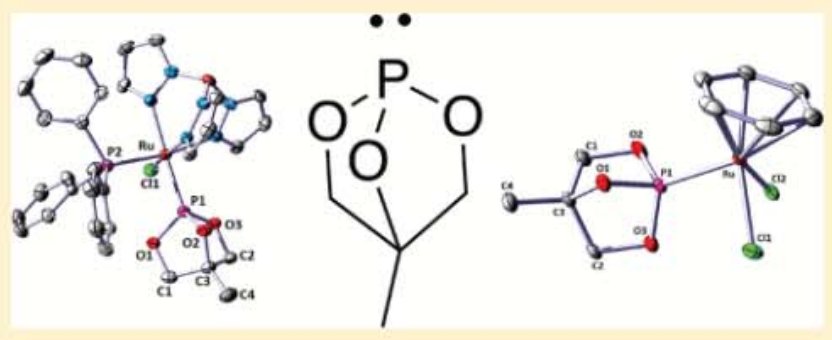

(14) or $\left.\mathrm{PPh}_{3}(15)\right]$ have been synthesized, isolated, and characterized by NMR spectroscopy, cyclic voltammetry, mass spectrometry, and, for some complexes, single crystal X-ray diffraction. Data from cyclic voltammetry and solid-state structures have been used to compare the properties of (1) with other phosphorus-based ligands as well as carbon monoxide. Data from the solid-state structures of $\mathrm{Ru}$ (II) complexes show that $\mathrm{P}\left(\mathrm{OCH}_{2}\right)_{2}\left(\mathrm{OCCH}_{3}\right)$ has a cone angle of 104 . Cyclic voltammetry data reveal that the $\mathrm{Ru}(\mathrm{II})$ complexes bearing $\mathrm{P}\left(\mathrm{OCH}_{2}\right)_{2}\left(\mathrm{OCCH}_{3}\right)$ have more positive $\mathrm{Ru}(\mathrm{III} / \mathrm{II})$ redox potentials than analogous complexes with the other phosphorus ligands; however, the $\mathrm{Ru}(\mathrm{III} / \mathrm{II})$ potential for $\left(\eta^{6}-\mathrm{C}_{6} \mathrm{H}_{6}\right) \mathrm{Ru}\left[\mathrm{P}\left(\mathrm{OCH}_{2}\right)_{2}\left(\mathrm{OCCH}_{3}\right)\right] \mathrm{Cl}_{2}$ is more negative compared to the $\mathrm{Ru}(\mathrm{III} / \mathrm{II})$ potential for the $\mathrm{CO}$ complex $\left(\eta^{6}-\mathrm{C}_{6} \mathrm{H}_{6}\right) \mathrm{Ru}(\mathrm{CO}) \mathrm{Cl}_{2}$. For the $\mathrm{Ru}$ (II) complexes studied herein, these data are consistent with the overall donor ability of 1 being less than other common phosphines (e.g., PMe ${ }_{3}$ or $\left.\mathrm{PPh}_{3}\right)$ or phosphites [e.g., $\mathrm{P}\left(\mathrm{OCH}_{2}\right)_{3} \mathrm{CEt}$ or $\mathrm{P}(\mathrm{OMe})_{3}$ ] but greater than carbon monoxide.

\section{INTRODUCTION}

Phosphorus-based compounds offer a wide range of steric properties and basicities because of the variety of accessible substituents. ${ }^{1} 16$ In addition, many phosphorus-based compounds bind strongly to transition metals. As a result of their coordinating ability and highly tunable stereoelectronic character, phosphorus-based compounds are among the most heavily utilized class of ligands in coordination chemistry and homogeneous catalysis. ${ }^{1}$ 3,5 7,9,16 19 Several studies have quantified the steric and donor properties of a wide range of phosphorus-based ligands. ${ }^{6,8,10}{ }_{16,20}{ }_{22}$ For example, the classic work by Tolman established the comparison of the steric properties of phosphorus ligands using cone angles. ${ }^{6}$ Recently, predicting the steric properties of phosphorus-based ligands has been improved using crystallographic data and computer modeling software. ${ }^{6,14,18}$ The donor abilities of phosphorus ligands have been studied using $\mathrm{CO}$ absorption energies for metal carbonyl complexes with phosphorus ligands [e.g., $\mathrm{Ni}(\mathrm{CO})_{3} \mathrm{~L}$ where $\mathrm{L}=$ phosphite, phosphine, etc..$^{6}$

Bicyclic phosphites have been investigated and compared to acyclic phosphites. In general, the steric profiles of bicyclic phosphites are constrained relative to acyclic compounds, and bicyclic phosphites exhibit reduced basicity relative to acyclic phosphites. Verkade has proposed the hinge effect to explain the influence of the bicyclic phosphites rigidity on basicity (Scheme 1).,23 26 Uncoordinated phosphites adopt a trigonal pyramidal geometry, while coordination (or protonation) of the phosphite results in a shift toward tetrahedral geometry. Upon coordination to a metal center, the $\mathrm{O} P \mathrm{O}$ and the $\mathrm{P} O \mathrm{C}$

Received: January 16, 2012

Published: March 27, 2012 
Scheme 1. Comparison of Acyclic and Bicyclic Phosphites Based on the Hinge Effect

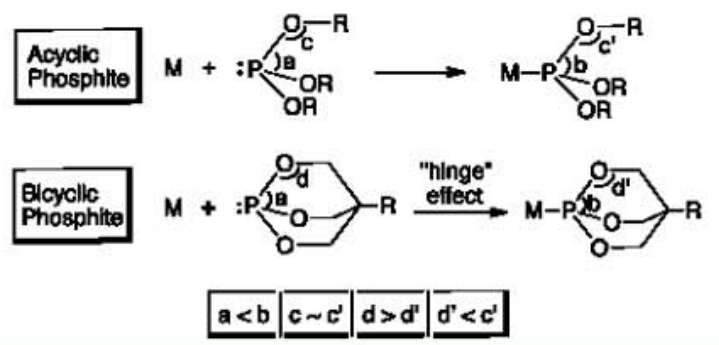

angles of an acyclic phosphite can adjust independently. But, reorganization of bicyclic phosphites upon metal ligation is more restricted because adjustment of the $\mathrm{O} P \mathrm{O}$ angle influences the P O C angle. For coordinated phosphites, bicyclic phosphites exhibit a smaller P O C angle compared to the acyclic phosphites (i.e., $\mathrm{d}<\mathrm{c}$ in Scheme 1). Verkade has proposed that these changes result in a reduction of the p-orbital overlap between $\mathrm{O}$ and $\mathrm{P}$, which increases the positive charge on the $\mathrm{P}$ atom and decreases the basicity relative to acyclic phosphites. Thus, the donor ability of bicyclic phosphites is reduced relative to related acyclic phosphites. ${ }^{27,28}$

A few bicyclic phosphites have been prepared and studied, and similar to acyclic phosphorus-based ligands their steric and donor properties are variable (Chart 1).,29 While several

Chart 1. Examples of Bicyclic Phosphites

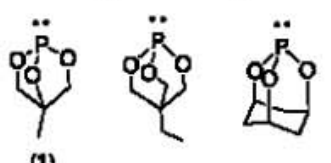

examples of transition metal complexes with bicyclic phosphite ligands are known, including nickel, cobalt, iron, chromium, molybdenum, and tungsten complexes, ${ }^{2} 4,3032$ to our knowledge, no examples of a structurally characterized transition metal complex with $\mathrm{P}\left(\mathrm{OCH}_{2}\right)_{2}\left(\mathrm{OCCH}_{3}\right)$ (1) (4-methyl-2,6,7-trioxa1-phosphabicyclo[2,2,1] heptane) is known. The structure of the phosphate $\mathrm{O}=\mathrm{P}\left(\mathrm{OCH}_{2}\right)_{2}\left(\mathrm{OCCH}_{3}\right)$ has been reported. ${ }^{29}$ Verkade et al. have studied a variety of polycyclic phosphorus compounds including their coordination to transition metals. $^{2,3,24,27,29,30}$ On the basis of trends in basicity, it is anticipated that 1 would be less donating to metal centers than the more commonly studied bicyclic phosphite $\mathrm{P}\left(\mathrm{OCH}_{2}\right)_{3} \mathrm{CEt}^{28}$

Phosphorus-based ligands are generally considered good donor ligands; but, the number of weakly donating ligands is small compared to strongly donating P-based ligands. We felt that phosphite $1 \mathrm{might}$ provide a relatively weakly donating phosphorus-based ligand. To study phosphite 1 and compare it to other phosphorus-based ligands, we sought suitable transition metal systems that would allow the coordination of several phosphorus-based ligands. Solid-state structures, redox properties (by cyclic voltammetry), and rates of ligand exchange have been studied for $\mathrm{TpRu}(\mathrm{L})\left(\mathrm{PPh}_{3}\right) \mathrm{Cl},\left(\eta^{6}-\mathrm{C}_{6} \mathrm{H}_{6}\right) \mathrm{Ru}(\mathrm{L}) \mathrm{Cl}_{2}$ and ( $\eta^{6}$-p-cymene) $\mathrm{Ru}(\mathrm{L}) \mathrm{Cl}_{2}$ complexes (Chart 2).

\section{RESULTS AND DISCUSSION}

The preparation of $\mathbf{1}$ from 2-methyl-1,2,3-propanetriol has been reported. ${ }^{33}$ Our attempts to synthesize and cleanly isolate
Chart 2. $\mathrm{TpRu}(\mathrm{L})\left(\mathrm{PPh}_{3}\right) \mathrm{Cl},\left(\eta^{6}-\mathrm{C}_{6} \mathrm{H}_{6}\right) \mathrm{Ru}(\mathrm{L}) \mathrm{Cl}_{2}$ and $\left(\eta^{6}-p\right.$ cymene) $\mathrm{Ru}(\mathrm{L}) \mathrm{Cl}_{2}$ Complexes Used to Study the Electronic and Steric Properties of Phosphite 1
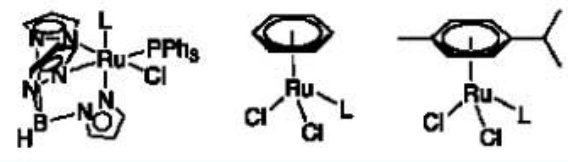

1 using this procedure were not successful. In addition, using alternate procedures reported for similar bicyclic phosphorus species did not result in the clean isolation of $1 .^{24,30,34,35}$ Thus, we developed a modified procedure that involves the in situ generation and subsequent reaction of 1 without isolation. ${ }^{36,37}$ The reaction of 2-methyl-1,2,3-propanetriol with $\mathrm{NaH}$ followed by treatment with $\mathrm{PCl}_{3}$ results in clean in situ formation of compound 1 , as evidenced by a single resonance at $115 \mathrm{ppm}$ in the ${ }^{31} \mathrm{P}$ NMR spectrum (eq 1 ).

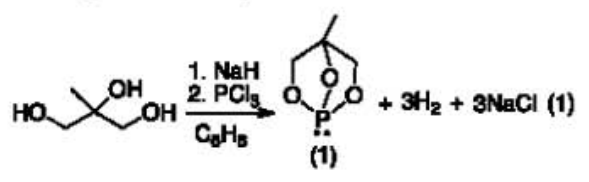

$\mathrm{TpRu}(\mathrm{L})\left(\mathrm{PPh}_{3}\right) \mathrm{Cl}$ Complexes. The addition of TpRu$\left(\mathrm{PPh}_{3}\right)_{2} \mathrm{Cl}$ to a benzene solution of 1 followed by reflux results in the formation of $\mathrm{TpRu}\left[\mathrm{P}\left(\mathrm{OCH}_{2}\right)_{2}\left(\mathrm{OCCH}_{3}\right)\right]\left(\mathrm{PPh}_{3}\right) \mathrm{Cl}$ (2) (eq 2).

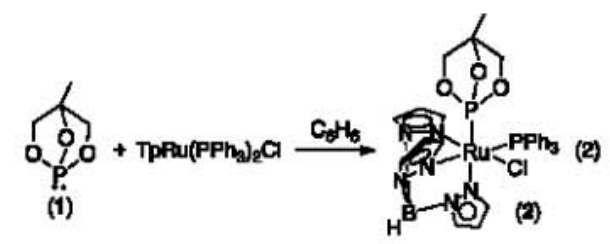

For 2, the methylene hydrogen atoms are diastereotopic, and the asymmetric complex exhibits four resonances due to the two $\mathrm{CH}_{2}$ groups with ${ }^{2} J_{\mathrm{HH}}=8 \mathrm{~Hz}$ and ${ }^{3} / \mathrm{HP}$ between 8 and $3.6 \mathrm{~Hz}$. In addition, $\mathrm{a}^{4} J_{\mathrm{HH}}$ of $1.4 \mathrm{~Hz}$ is observed for two of the hydrogen atoms (Table 1).

Table 1. Coupling Constants Observed for the Ligand $\mathrm{P}\left(\mathrm{OCH}_{2}\right)_{2}\left(\mathrm{OCCH}_{3}\right)(1)$ in the ${ }^{1} \mathrm{H}$ NMR Spectrum of $\mathrm{TpRu}\left[\mathrm{P}\left(\mathrm{OCH}_{2}\right)_{2}\left(\mathrm{OCCH}_{3}\right)\right] \mathrm{PPh}_{3} \mathrm{Cl}$

\begin{tabular}{|c|c|c|c|c|}
\hline \multirow{5}{*}{ 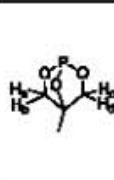 } & & ${ }^{2} J_{H H}$ & ${ }^{3} J_{K P}$ & ${ }^{4} J_{\text {HR }}$ \\
\hline & $\mathbf{H}_{\mathbf{2}}$ & $8.0 \mathrm{~Hz}$ & $8.0 \mathrm{~Hz}$ & 5 \\
\hline & $\mathbf{H}_{\mathbf{b}}$ & $8.0 \mathrm{~Hz}$ & $3.6 \mathrm{~Hz}$ & $1.4 \mathrm{~Hz}$ \\
\hline & $\mathbf{H}_{0}$ & $8.0 \mathrm{Kz}$ & $8.0 \mathrm{~Hz}$ & $\Rightarrow$ \\
\hline & $\mathrm{H}_{d}$ & $8.0 \mathrm{~Hz}$ & $3.6 \mathrm{~Hz}$ & $1.4 \mathrm{~Hz}$ \\
\hline
\end{tabular}

${ }^{a} \mathrm{~A}$ third coupling constant was not resolved for these resonances.

An X-ray diffraction study (Table 2) was performed on a crystal of complex 2 (Figure 1). A search of the Cambridge Structural Database revealed no other examples of structures with phosphite 1 . We have previously reported the structure of $\left.\mathrm{TpRu}\left[\mathrm{P}\left(\mathrm{OCH}_{2}\right)_{3} \mathrm{CEt}\right]\left(\mathrm{PPh}_{3}\right) \mathrm{Cl}(3)\right)^{31}$ The $\mathrm{Ru} \mathrm{P}_{\text {phosphite }}$ bond lengths for complexes 2 and 3 are 2.191(1) $\AA$ and $2.2025(8) \AA$, respectively. Thus, phosphite 1 exhibits a slightly shorter Ru $\mathrm{P}_{\text {phosphite }}$ bond distance than $\mathrm{P}\left(\mathrm{OCH}_{2}\right)_{3} \mathrm{CEt}$. The average $\mathrm{P}_{\text {phosphite }} \mathrm{O}$ bond distance for complex 2 is $1.627(3) \AA$, whereas complex 3 has a shorter average $\mathrm{P}_{\text {phosphite }} \mathrm{O}$ bond length of $1.605(2) \mathrm{A}$. The longer P O bond distances for 2 
Table 2. Selected Crystallographic Data for $\mathrm{TpRu}\left(\mathrm{PPh}_{3}\right)\left[\mathrm{P}\left(\mathrm{OCH}_{2}\right)_{2}\left(\mathrm{OCCH}_{3}\right)\right] \mathrm{Cl}(2),\left(\eta^{6}-\mathrm{C}_{6} \mathrm{H}_{6}\right)-$ $\mathrm{Ru}\left[\mathrm{P}\left(\mathrm{OCH}_{2}\right)_{2}\left(\mathrm{OCCH}_{3}\right)\right] \mathrm{Cl}_{2}(11)$, and $\left(\eta^{6}-p\right.$-cymene $)$ $\mathrm{Ru}\left[\mathrm{P}\left(\mathrm{OCH}_{2}\right)_{2}\left(\mathrm{OCCH}_{3}\right)\right] \mathrm{Cl}_{2}(12)$

\begin{tabular}{|c|c|c|c|}
\hline & complex $2 \mathrm{CH}_{2} \mathrm{Cl}_{2}$ & $11 \stackrel{\text { complex }}{\left(\mathrm{CHCl}_{3}\right)_{2}}$ & $12 \stackrel{\text { complex }}{\left(\mathrm{CH}_{2} \mathrm{Cl}_{2}\right)_{2}}$ \\
\hline empirical formula & $\mathrm{C}_{32} \mathrm{H}_{34} \mathrm{BCl}_{3} \mathrm{~N}_{6} \mathrm{O}_{3} \mathrm{P}_{2} \mathrm{Ru}$ & $\mathrm{C}_{12} \mathrm{H}_{15} \mathrm{Cl}_{8} \mathrm{O}_{3} \mathrm{PRu}$ & $\mathrm{C}_{18} \mathrm{H}_{29} \mathrm{Cl}_{6} \mathrm{O}_{3} \mathrm{PRu}$ \\
\hline fw & 830.82 & 622.88 & 638.15 \\
\hline cryst syst & monoclinic & monoclinic & monoclinic \\
\hline space group & $P 2_{1} / c$ & $P 2_{1} / c$ & $P 2_{1} / n$ \\
\hline$a, \AA$ & $14.5126(3)$ & $10.219(1)$ & $10.7611(3)$ \\
\hline$b, \AA$ & $13.5883(3)$ & $10.518(1)$ & $10.4473(3)$ \\
\hline$c, \AA$ & $17.8390(4)$ & $20.162(2)$ & $22.4999(6)$ \\
\hline$\beta$, deg & $93.643(1)$ & $99.416(1)$ & $99.312(1)$ \\
\hline$V, \AA^{3}$ & $3510.8(1)$ & $2137.9(4)$ & $2496.2(1)$ \\
\hline$Z$ & 4 & 4 & 4 \\
\hline$D_{\text {calcd, }} \mathrm{mg} / \mathrm{m}^{3}$ & 1.572 & 1.935 & 1.698 \\
\hline cryst size, $\mathrm{mm}$ & $\begin{array}{lll}0.31 & 0.12 & 0.07\end{array}$ & $\underset{0.11}{0.34} 0.12$ & $\begin{array}{c}0.45 \\
0.14\end{array}$ \\
\hline $\begin{array}{l}\mathrm{R} 1 \text {, wR2 } \\
\quad(I>2 \sigma(I))\end{array}$ & $0.0346,0.0994$ & $0.0492,0.1298$ & $0.0253,0.0965$ \\
\hline GOF & 0.833 & 1.056 & 0.863 \\
\hline
\end{tabular}

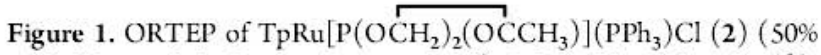
probability with hydrogen atoms omitted). Selected bond lengths $(\hat{\mathrm{A}})$ : Ru P1，2.191(1); Ru P2, 2.342(1); P O1, 1.627(3); P O2, 1.632(3); P O3, 1.620(3). Selected bond angles (deg): P1 Ru P2, 94.1(4); O3 P1 O1, 100.2(1); O3 P1 O2, 94.6(1); O1 P1 O2, 95.0(1); O1 P1 Ru, 118.5(1); O2 P1 Ru, 126.2(1); O3 P1 Ru, 116.8(1); C1 O1 P1, 107.3(2); C3 O2 P1, 97.5(2); C2 O3 P1, 107.4(2).

[compared to $\mathrm{P}\left(\mathrm{OCH}_{2}\right)_{3} \mathrm{CEt}$ ] are anticipated if ligand $\mathbf{1}$ functions as a better $\pi$-acid than $\mathrm{P}\left(\mathrm{OCH}_{2}\right)_{3} \mathrm{CEt}$ and the $\mathrm{d} \pi$ backbonding involves the P O $\sigma^{*}$ orbitals. ${ }^{1}$ Complex 2 exhibits one larger $[100.2(1)]$ and two smaller $[94.6(1)$ and 95.0(1) ] O P O bond angles. The O2 P1 Ru angle in complex 2 is 126.2(1), whereas the O3 P1 Ru and O1 P1 $\mathrm{Ru}$ angles are 116.80(1) and 118.49(1). The O3 $\mathrm{P}_{\text {phosphite }}$ $\mathrm{Ru}$ angles $[118.33(9), 113.34(9)$, and $118.79(9)]$ of 3 are similar to the same angles with $\mathrm{O} 1$ and $\mathrm{O} 3$ of complex 2 . For the $\mathrm{C}_{\text {phosphite }} \mathrm{O} \mathrm{P}_{\text {phosphite }}$ angles, complex 2 has one angle smaller than the other two $[97.5(2)$ vs $107.3(2)$ and 107.4(2) ]. For complex 3, all the angles for $\mathrm{C}_{\text {phosphite }} \mathrm{O} \mathrm{P}_{\text {phosphite }}$ are similar at $116.9(2), 115.8(2)$, and $116.5(2)$. Thus, the $\mathrm{C}_{\text {phosphite }} \mathrm{O} \mathrm{P}_{\text {phosphite }}$ angles of $\mathbf{2}$ are smaller than $\mathbf{3}$, which is consistent with a more pronounced hinge effect (Scheme 1) for 1 compared to $\mathrm{P}\left(\mathrm{OCH}_{2}\right)_{3} \mathrm{CEt}$. Cone angles were calculated from crystallographic data for the phosphite ligands of complexes 2 and 3 . Using the $\mathrm{P} 1 \mathrm{Ru} O \mathrm{O}$ angles and the van der Waals radius for oxygen, the cone angle for complex 2 was determined to be 104 , whereas complex 3 is slightly larger at 108 (see Supporting Information). ${ }^{14}$ The cone angle of $\mathrm{P}(\mathrm{OMe})_{3}$ is 107.6

In addition to 2 and 3 , we prepared $\mathrm{TpRu}\left(\mathrm{PMe}_{3}\right)\left(\mathrm{PPh}_{3}\right) \mathrm{Cl}$ (4) and $\mathrm{TpRu}\left[\mathrm{P}(\mathrm{OMe})_{3}\right]\left(\mathrm{PPh}_{3}\right) \mathrm{Cl}(5) .^{38}$ The relative donorability of 1 [compared to $\mathrm{PMe}_{3}, \mathrm{P}(\mathrm{OMe})_{3}$, and $\mathrm{P}\left(\mathrm{OCH}_{2}\right)_{3} \mathrm{CEt}$ ] was probed by comparing the $\mathrm{Ru}(\mathrm{III} / \mathrm{II})$ redox potentials of $\mathrm{TpRu}(\mathrm{L})\left(\mathrm{PPh}_{3}\right) \mathrm{Cl}\left[\mathrm{L}=\mathrm{P}\left(\mathrm{OCH}_{2}\right)_{2}\left(\mathrm{OCCH}_{3}\right)(2), \mathrm{P}\left(\mathrm{OCH}_{2}\right)_{3}\right.$ $\mathrm{CEt}(3), \mathrm{PMe}_{3}(4)$, and $\left.\mathrm{P}(\mathrm{OMe})_{3}(5)\right]$ complexes (Chart 3).

Chart 3. $\mathrm{Ru}(\mathrm{III} / \mathrm{II})$ Potentials for $\mathrm{TpRu}(\mathrm{L})\left(\mathrm{PPh}_{3}\right) \mathrm{Cl}$ Complexes $^{a}$

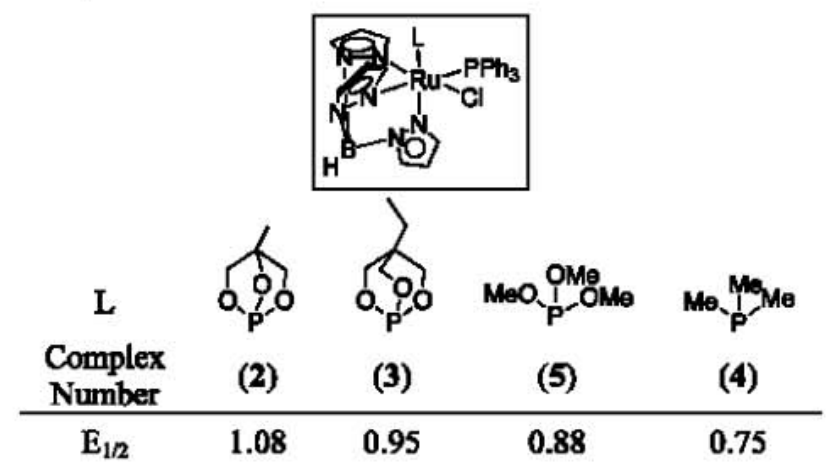

${ }^{a}$ Data from cyclic voltammetry in $\mathrm{NCCH}_{3}$ with reversible potentials $\left(E_{1 / 2}\right)$ reported vs NHE (in V).

The $\mathrm{Ru}(\mathrm{III} / \mathrm{II})$ potentials indicate the following trend in overall donor ability: $\mathrm{PMe}_{3}>\mathrm{P}(\mathrm{OMe})_{3}>\mathrm{P}\left(\mathrm{OCH}_{2}\right)_{3} \mathrm{CEt}>1$. The $\mathrm{Ru}(\mathrm{III} / \mathrm{II})$ potentials of complexes 2 and 3 differ by $0.13 \mathrm{~V}$ ( 1.08 and $0.95 \mathrm{~V}$, respectively) with the potential of 2 positive compared to the potential of 3 , thus supporting the hypothesis that ligand 1 is less donating overall than $\mathrm{P}\left(\mathrm{OCH}_{2}\right)_{3} \mathrm{CEt}$.

$\left(\eta^{6}-\mathrm{C}_{6} \mathrm{H}_{6}\right) \mathrm{Ru}(\mathrm{L}) \mathrm{Cl}_{2}$ Complexes. To gain further insight into the donor ability of 1 , we prepared a series of $\left(\eta^{6}-\mathrm{C}_{6} \mathrm{H}_{6}\right)$. $\mathrm{Ru}(\mathrm{L}) \mathrm{Cl}_{2}$ complexes $\left[\mathrm{L}=\mathrm{PPh}_{3}(6), \mathrm{P}(\mathrm{OMe})_{3}(7), \mathrm{PMe}_{3}(8)\right.$, $\mathrm{P}\left(\mathrm{OCH}_{2}\right)_{3} \mathrm{CEt}(9), \mathrm{CO}(10)$, and $\left.\mathrm{P}\left(\mathrm{OCH}_{2}\right)_{2}\left(\mathrm{OCCH}_{3}\right)(11)\right]$ (Chart 2). ${ }^{39} 45$ The syntheses of complexes 6,7 , and 10 have been previously reported. ${ }^{39,40}$ A procedure similar to the synthesis of complex 7 was followed in the preparation of complexes 8,9 , and 11 , which involves stirring commercially available $\left[\left(\eta^{6}-\mathrm{C}_{6} \mathrm{H}_{6}\right) \mathrm{Ru}(\mathrm{Cl})(\mu \text { - } \mathrm{Cl})\right]_{2}$ with excess $\mathrm{L}$ in dichloromethane (eq 3).

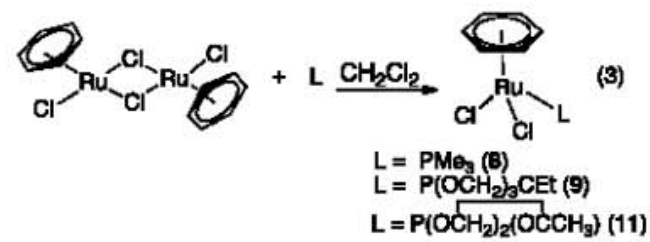

A single crystal of 11 suitable for an X-ray diffraction study was grown (Figure 2). The phosphite ligand of 11 has features that are similar to complex 2 . For example, there is one larger [102.5(1) ] and two smaller [95.77(9) and 96.38(1)] O P $\mathrm{O}$ angles. The C3 O1 PI angle $[96.89(1)]$ is substantially smaller than the other two C O P angles, which are 106. 


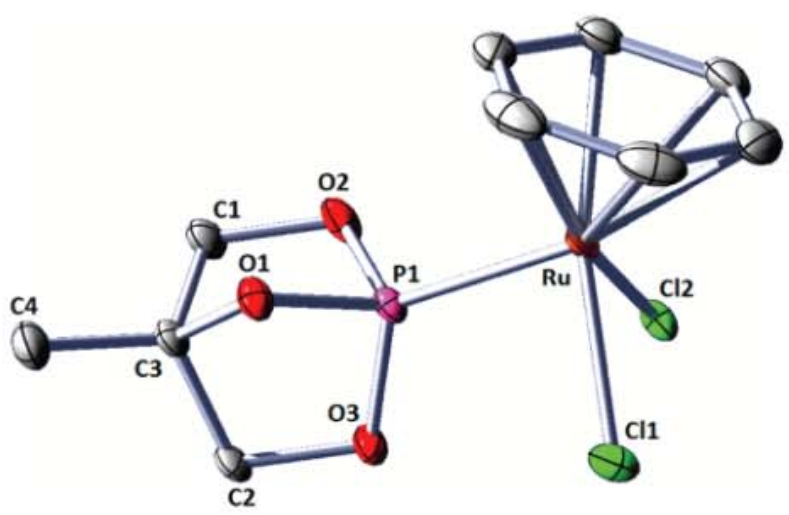

Figure 2. ORTEP diagram of $\left(\eta^{6}-\mathrm{C}_{6} \mathrm{H}_{6}\right) \mathrm{Ru}\left[\mathrm{P}\left(\mathrm{OCH}_{2}\right)_{2}\left(\mathrm{OCCH}_{3}\right)\right] \mathrm{Cl}_{2}$ (11) (50\% probability with hydrogen atoms omitted). Selected bond lengths $(\AA)$ : Ru P1, 2.2453(7); P1 O1, 1.615(2); P1 O2, 1.616(2); $\mathrm{P} 1 \mathrm{O} 3,1.607(2)$; Avg. $\mathrm{C}_{(\mathrm{C} 6 \mathrm{H} 6)} \mathrm{Ru}, 2.198(1)$. Selected bond angles (deg): O1 P1 O2, 95.77(9); O3 P1 O1, 96.38(1); O3 P1 O2 102.5(1); Cl1 Ru Cl2, 87.33(2); P1 Ru Cl1, 88.66(2); P1 Ru $\mathrm{Cl} 2,84.03(2)$; C3 O1 P1 96.89(1); C1 O2 P1 106.58(1); C2 O3 P1 106.24(1).

The cone angle of $\mathrm{P}\left(\mathrm{OCH}_{2}\right)_{2}\left(\mathrm{OCCH}_{3}\right)$ calculated from the structure of complex 11 is 104 , which is identical to that determined using the structure of complex 2. The average $\mathrm{P} O$ bond distances for $11[1.613(2) \AA]$ are longer than those for the $\mathrm{P}\left(\mathrm{OCH}_{2}\right)_{3} \mathrm{CEt}$ complex $3[1.605(2) \AA]$, but not as long as those of complex 2 [1.627(3) A, see above]. Table 3 shows

Table 3. Selected Bond Lengths and Angles Comparing of 2, 7 , and $11^{a}$

$\begin{array}{clcccc}\text { complex } & \text { O P O (deg) } & \text { C O P (deg) } & \text { O P Ru (deg) } & \text { P O (A) } \\ 2 & 100.2(1) & 97.5(2) & 118.5(1) & 1.627(3) \\ & 94.6(1) & 107.3(2) & 126.2(1) & 1.632(3) \\ & 95.0(1) & 107.4(2) & 116.8(1) & 1.620(3) \\ 7 & 107.0(2) & 123.1(3) & 111.2(1) & 1.565(3) \\ & 98.7(2) & 131.4(3) & 123.4(1) & 1.569(3) \\ & 97.5(2) & 119.4(3) & 115.7(1) & 1.594(3) \\ 11 & 102.5(1) & 96.89(1) & 121.20(7) & 1.615(2) \\ & 95.77(9) & 106.58(1) & 120.98(6) & 1.616(2) \\ & 96.38(1) & 106.24(1) & 115.31(8) & 1.607(2)\end{array}$

${ }^{a}$ The structure of 7 has been previously reported. ${ }^{41}$

some comparative geometric data for complexes 2, 11, and the previously reported complex $\left(\eta^{6}-\mathrm{C}_{6} \mathrm{H}_{6}\right) \mathrm{Ru}\left[\mathrm{P}(\mathrm{OMe})_{3}\right] \mathrm{Cl}_{2}(7)^{41}$

The $\left(\eta^{6}-\mathrm{C}_{6} \mathrm{H}_{6}\right) \mathrm{Ru}(\mathrm{L}) \mathrm{Cl}_{2}$ complexes were studied using cyclic voltammetry (Chart 4). For $\left(\eta^{6}-\mathrm{C}_{6} \mathrm{H}_{6}\right) \mathrm{Ru}^{1 \mathrm{II}}$ complexes, irreversible $\mathrm{Ru}(\mathrm{III} / \mathrm{II})$ potentials are often observed, possibly because of dissociation of the benzene ligand in the oxidized $\mathrm{Ru}(\mathrm{III})$ state. ${ }^{44}$ For the $\left(\eta^{6}-\mathrm{C}_{6} \mathrm{H}_{6}\right) \mathrm{Ru}(\mathrm{L}) \mathrm{Cl}_{2}$ complexes studied herein, some complexes exhibit quasi-reversible $\mathrm{Ru}(\mathrm{III} / \mathrm{II})$ potentials while others have chemically irreversible potentials. To standardize comparisons, we use $E_{\mathrm{p}, \mathrm{a}}$ and $E_{\mathrm{p}, \mathrm{c}}$ in the discussions below since the redox waves for complexes 9, 10, and 11 are not reversible. The carbonyl complex $\left(\eta^{6}-\mathrm{C}_{6} \mathrm{H}_{6}\right) \mathrm{Ru}-$ (CO) $\mathrm{Cl}_{2}(10)$, with $E_{\mathrm{p}, \mathrm{a}}=+1.78 \mathrm{~V}$ (vs NHE), was used as a benchmark to compare the donor ability of 1 because of the strong $\pi$-acidity of the $\mathrm{CO}$ ligand. The $E_{\mathrm{p}, \mathrm{a}}$ for complex 11 $(1.50 \mathrm{~V})$ is $0.28 \mathrm{~V}$ more negative than the $E_{p, a}$ for the CO complex 10, indicating that the phosphite $\mathbf{1}$ is more donating than $\mathrm{CO}$. Consistent with the $\mathrm{TpRu}(\mathrm{L})\left(\mathrm{PPh}_{3}\right) \mathrm{Cl}$ complexes (see above), the $\mathrm{Ru}(\mathrm{III} / \mathrm{II})$ potentials for the $\left(\eta^{6}-\mathrm{C}_{6} \mathrm{H}_{6}\right) \mathrm{Ru}(\mathrm{L}) \mathrm{Cl}_{2}$ complexes indicate the following trend in overall donating ability: $\mathrm{PMe}_{3}\left(\right.$ complex 8) $>\mathrm{P}(\mathrm{OMe})_{3}($ complex 7$)>\mathrm{P}\left(\mathrm{OCH}_{2}\right)_{3} \mathrm{CEt}$ (complex 6) $\quad \mathrm{PPh}_{3}\left(\right.$ complex 9) $>\mathrm{P}\left(\mathrm{OCH}_{2}\right)_{2}\left(\mathrm{OCCH}_{3}\right)$ (complex 11) (Chart 4). Of the phosphines and phosphites studied, complex 11 yields a metal center with the most positive potential with $E_{\mathrm{p}, \mathrm{a}}=1.50 \mathrm{~V}$.

In addition to the $\mathrm{Ru}(\mathrm{III} / \mathrm{II})$ potentials, a cathodic wave $\left(E_{\mathrm{p}, \mathrm{c}}\right)$ is observed for each $\left(\eta^{6}-\mathrm{C}_{6} \mathrm{H}_{6}\right) \mathrm{Ru}(\mathrm{L}) \mathrm{Cl}_{2}$ complex (Chart 4). The $\mathrm{P}(\mathrm{OMe})_{3}$ complex 7 displays a two-electron reduction at $0.94 \mathrm{~V}^{46}$ Two one-electron reductions are observed for complex 6, at $E_{\mathrm{p}, \mathrm{a}}=0.85$ and $1.07 \mathrm{~V}$. All of the other complexes exhibit single-electron reductions. As the electron density of the metal center decreases, one would expect the $E_{\mathrm{p}, \mathrm{c}}$ to become less negative. Indeed, complexes 10 and 11 have the least negative reduction potentials, 0.50 and $0.99 \mathrm{~V}$, respectively.

( $\eta^{6}$-p-cymene) $\mathrm{Ru}(\mathrm{L}) \mathrm{Cl}_{2}$ Complexes. Another group of metal complexes containing phosphites/phosphines is $\left(\eta^{6}-p\right.$ cymene) $\mathrm{Ru}(\mathrm{L}) \mathrm{Cl}_{2}{ }^{5,47} 49$ Similar to the $\left(\eta^{6}-\mathrm{C}_{6} \mathrm{H}_{6}\right) \mathrm{Ru}(\mathrm{L}) \mathrm{Cl}_{2}$, the complexes $\left(\eta^{6}-p\right.$-cymene $) \mathrm{Ru}\left[\mathrm{P}\left(\mathrm{OCH}_{2}\right)_{3} \mathrm{CEt}\right] \mathrm{Cl}_{2}$ (12), ( $\eta^{6}$-p-cymene $) \mathrm{Ru}\left[\mathrm{P}\left(\mathrm{OCH}_{2}\right)_{2}\left(\mathrm{OCCH}_{3}\right)\right] \mathrm{Cl}_{2}(13)$, ( $\eta^{6}$-p-cymene $)$ $\mathrm{Ru}\left[\mathrm{P}(\mathrm{OMe})_{3}\right] \mathrm{Cl}_{2}(14)$, and $\left(\eta^{6}-p\right.$-cymene $) \mathrm{Ru}\left(\mathrm{PPh}_{3}\right) \mathrm{Cl}_{2}$ (15) were synthesized by the reaction of $\left[\left(\eta^{6}-p\right.\right.$-cymene $) \mathrm{Ru}(\mathrm{Cl})(\mu$ $\mathrm{Cl})]_{2}$ with excess $\mathrm{L}$ in dichloromethane (eq 4$)$.

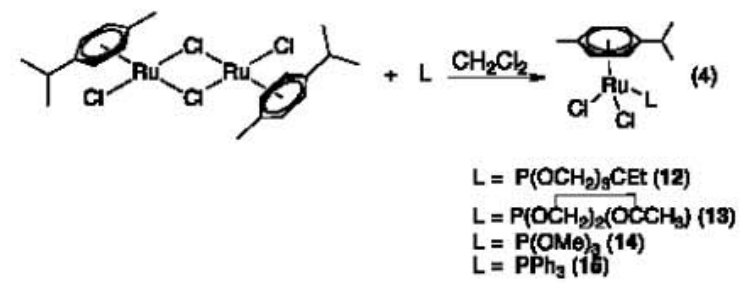

A single crystal suitable for X-ray diffraction was grown of complex 12 (Figure 3). On the basis of previously reported data, the $\mathrm{Ru} \mathrm{P}$ bond distance increases with the following trend $\mathrm{P}\left(\mathrm{OCH}_{2}\right)_{3} \mathrm{CEt}(12)<\mathrm{P}(\mathrm{OPh})_{3}<\mathrm{PPh}_{3}(15)<\mathrm{P}\left(\mathrm{NC}_{4} \mathrm{H}_{4}\right)_{3}$ (Table 4). ${ }^{5,47,49}$ Furthermore, when comparing the $\mathrm{O} P \mathrm{O}$ bond angles of complexes 2,11 , and $\mathbf{1 2}$, removal of the methylene group to form phosphite 1 results in a substantial decrease in one of the $\mathrm{OP} \mathrm{P}$ bond angles by approximately 5 . The $\mathrm{Ru} \mathrm{P}$ bond length for complex 12 [2.2529(4) $\AA]$ is longer than that for complex $2[2.191(1) \AA]$ and $11[2.2453(7) \AA]$. Additionally, the average $\mathrm{P} O \mathrm{O}$ bond lengths for complex 2 $(1.626 \AA)$ and $11(1.613 \AA)$ are longer than complex 12 $(1.597 \AA)$, consistent with phosphite 1 being a better $\pi$-acid than $\mathrm{P}\left(\mathrm{OCH}_{2}\right)_{3} \mathrm{CEt}$.

Complexes 1215 were studied using cyclic voltammetry (Chart 5). It was determined that the least electron density on the metal center is observed for complex 13 where $E_{1 / 2}=1.44$, $E_{\mathrm{p}, \mathrm{a}}=1.47 \mathrm{~V}$ and $E_{\mathrm{p}, \mathrm{c}}=1.44 \mathrm{~V}$. This observation is consistent with data collected for the $\eta^{6}-\mathrm{C}_{6} \mathrm{H}_{6}$ systems (see above). When using $E_{1 / 2}$ values the same trend is apparent (Chart 5).

Kinetic Studies for Phosphine/Phosphite Exchange. As a final probe of the properties of 1 as a ligand, we compared the rate of exchange of $\mathrm{L}$ with $\mathrm{P}(\mathrm{OMe})_{3}$ for $\left(\eta^{6}-p\right.$-cymene)$\mathrm{Ru}(\mathrm{L}) \mathrm{Cl}_{2}$ complexes $\left[\mathrm{L}=1, \mathrm{P}\left(\mathrm{OCH}_{2}\right)_{3} \mathrm{CEt}\right.$ and $\left.\mathrm{PPh}_{3}\right]$. The exchange rates were determined under pseudofirst-order conditions by monitoring the disappearance of ( $\eta^{6}$ - $p$-cymene)$\mathrm{Ru}(\mathrm{L}) \mathrm{Cl}_{2}$ in the presence of excess $\mathrm{P}(\mathrm{OMe})_{3}$ with ${ }^{1} \mathrm{H}$ NMR spectroscopy. Figure 4 displays plots of concentration of $\mathrm{Ru}$ 
Chart 4. $\mathrm{Ru}(\mathrm{III} / \mathrm{II})$ Potentials for $\left(\eta^{6}-\mathrm{C}_{6} \mathrm{H}_{6}\right) \mathrm{Ru}_{(\mathrm{L}) \mathrm{Cl}_{2} \text { Complexes }}{ }^{a}$

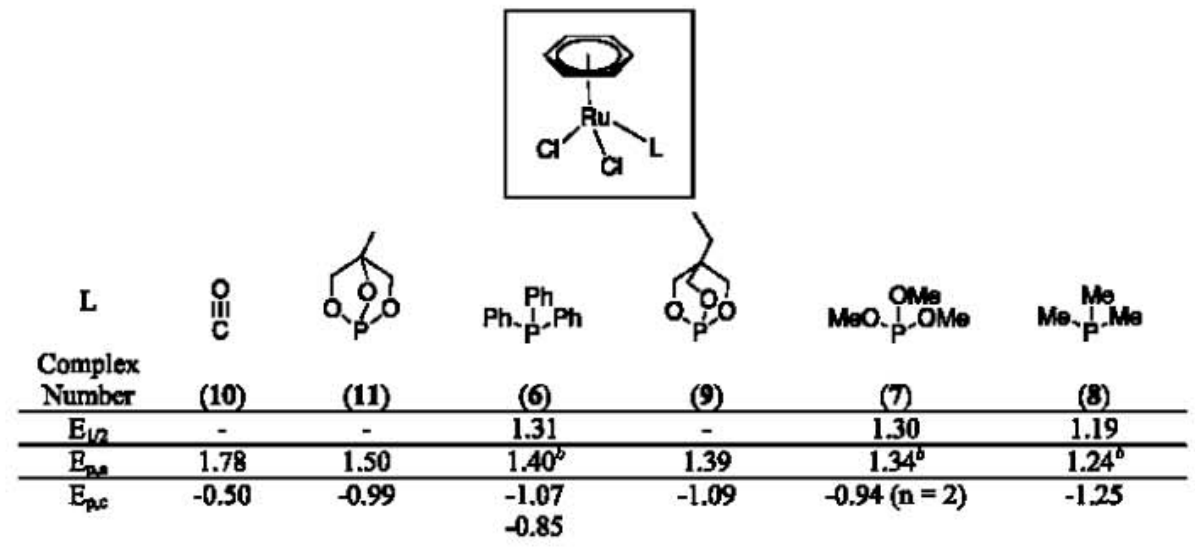

${ }^{a}$ Data from cyclic voltammetry in $\mathrm{NCCH}_{3}$ with potentials reported vs NHE (in V). ${ }^{b}$ Denotes quasi-reversible potential.

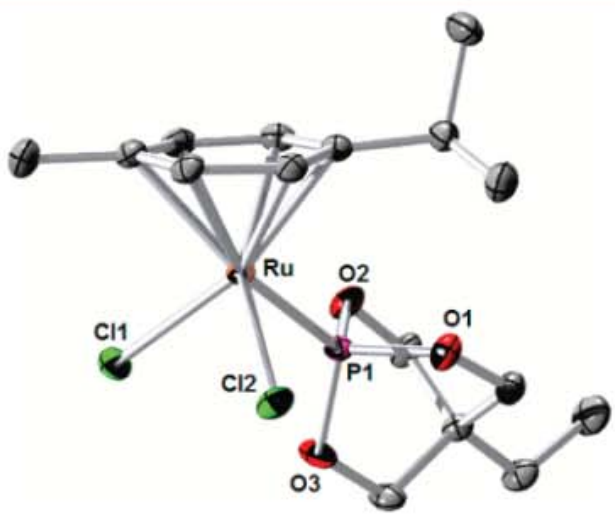

Figure 3. ORTEP of $\left(\eta^{6}-p\right.$-cymene $) \mathrm{Ru}\left[\mathrm{P}\left(\mathrm{OCH}_{2}\right)_{3} \mathrm{CEt}\right] \mathrm{Cl}_{2}(12)(50 \%$ probability with hydrogen atoms omitted). Selected bond lengths $(\AA)$ : Ru P1, 2.2529(4); P1 O1, 1.599(1); P1 O2, 1.599(1); P1 O3, 1.594(1). Selected bond angles (deg): O3 P1 O2, 102.82(6); O3 P1 O1, 102.37(6); O2 P1 O1, 102.31(6); Cl1 Ru Cl2, 88.59(1); P1 Ru Cl1, 88.10(1); P1 Ru Cl2, 83.91(1).

Table 4. Comparison of Bond Lengths from Crystallographic Data for $\left(\eta^{6}-p\right.$-cymene $) \mathrm{Ru}(\mathrm{L}) \mathrm{Cl}_{2}$ Complexes

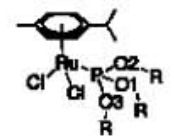

\begin{tabular}{lllll}
\multicolumn{1}{c}{ P-Ligand } & Ru P1 $(\AA)$ & P1 O1 $(\AA)$ & P1 O2 $(A)$ & P1 O3 $(\AA)$ \\
$\mathrm{PPh}_{3}$ & $2.3438(6)$ & $a$ & $a$ & $a$ \\
$\mathrm{P}\left(\mathrm{OCH}_{2}\right)_{3} \mathrm{CEt}$ & $2.2529(4)$ & $1.599(1)$ & $1.599(1)$ & $1.594(1)$ \\
$\mathrm{P}\left(\mathrm{NC}_{4} \mathrm{H}_{4}\right)_{3}$ & $2.396(2)$ & $a$ & $a$ & $a$ \\
$\mathrm{P}(\mathrm{OPh})_{3}$ & $2.2642(8)$ & $1.596(2)$ & $1.607(2)$ & $1.584(2)$ \\
${ }^{a} \mathrm{No}$ oxygen atom in P-based ligand. & &
\end{tabular}

${ }^{a}$ No oxygen atom in P-based ligand.

complex vs time for 12,13 , and $\mathbf{1 5}$. The $k_{\mathrm{obs}}$ values for each reaction were determined by fitting the plots to first-order decays, which gives the following relative $k_{\text {obs }}$ magnitudes: 15 $\left[k_{\mathrm{obs}}=0.0045(3) \mathrm{s}^{1}\right]>13\left[k_{\mathrm{obs}}=0.0030(1) \mathrm{s}^{1}\right] \quad 12\left[k_{\mathrm{obs}}=\right.$ $\left.8.5(6) 10^{5} \mathrm{~s}^{1}\right]$.

Figure 5 shows a plot of $k_{\mathrm{obs}}$ vs concentration of $\mathrm{PPh}_{3}$ for the reaction of 15 with $\mathrm{P}(\mathrm{OMe})_{3}$. Increasing the concentration of $\mathrm{PPh}_{3}$ decreases the rate of ligand exchange indicating an inverse rate dependence on concentration of $\mathrm{PPh}_{3}$. Figure 6 displays a plot of $k_{\text {vbs }}$ vs concentration of $\mathrm{P}(\mathrm{OMe})_{3}$ for the reaction of 15
Chart 5. $\mathrm{Ru}(\mathrm{III} / \mathrm{II})$ Potentials for $\left(\eta^{6}-p\right.$-cymene $) \mathrm{Ru}(\mathrm{L}) \mathrm{Cl}_{2}$ Complexes $^{a}$

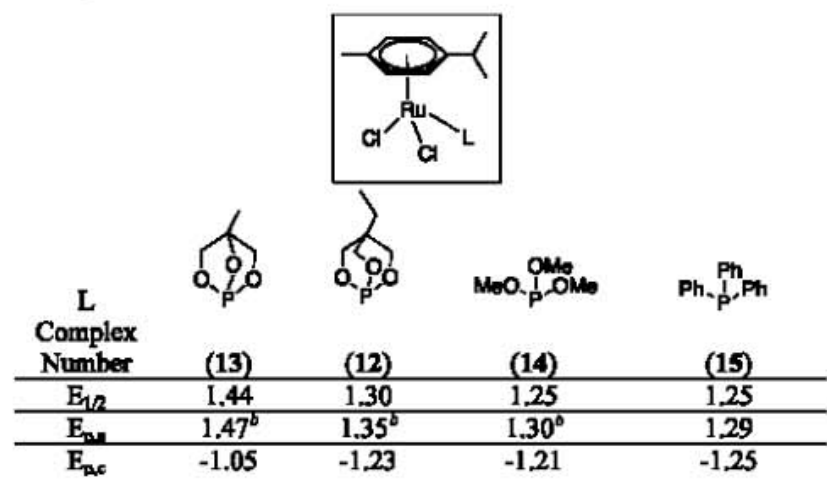

${ }^{a}$ Data from cyclic voltammetry in $\mathrm{NCCH}_{3}$ with potentials reported vs NHE (in V). ${ }^{b}$ Denotes quasi-reversible potential.

with $\mathrm{P}(\mathrm{OMe})_{3}$. The rate of reaction initially increases, and saturation is observed at higher concentrations of $\mathrm{P}(\mathrm{OMe})_{3}$. Scheme 2 shows a potential reaction pathway for the conversion of 12,13 , or 15 and $\mathrm{P}(\mathrm{OMe})_{3}$ to $\left(\eta^{6}-p\right.$-cymene $) \mathrm{Ru}-$ $\left[\mathrm{P}(\mathrm{OMe})_{3}\right] \mathrm{Cl}_{2}$ that is consistent with the kinetic data for the reaction of 15 and $\mathrm{P}(\mathrm{OMe})_{3}$ (see the rate law shown in eq 5 for

$$
\text { Rate }=\frac{\mathrm{k}_{1} \mathrm{k}_{2}\left[\mathrm{P}(\mathrm{OMe})_{3}\right][\mathrm{Ru} \text { Complex }]}{\mathrm{k}_{1}[\mathrm{~L}]+\mathrm{k}_{2}\left[\mathrm{P}(\mathrm{OMe})_{3}\right]}
$$

this pathway). Since 12, 13, and $\mathbf{1 5}$ are 18-electron complexes, a ligand exchange by a dissociative pathway is reasonable. Under saturation conditions \{where $\left.k_{2}\left[\mathrm{P}(\mathrm{OMe})_{3}\right]>k_{1}[\mathrm{~L}]\right\}$, the rate law can be reduced to rate $=k_{1}[\mathrm{Ru}$ complex $]$ where $k_{\text {obs }}$ $=k_{1}$, which is the rate constant for dissociation of $\mathrm{L}$. Thus, the $k_{\text {obs }}$ values derived from the kinetic plots in Figure 4 should provide relative rates of dissociation of $\mathrm{L}$ from $\left(\eta^{6}-p\right.$ cymene) $\mathrm{Ru}(\mathrm{L}) \mathrm{Cl}_{2}$ complexes. The $k_{\text {obs }}$ values indicate that the rate of dissociation of 1 is similar to that of $\mathrm{PPh}_{3}$, and that 1 and $\mathrm{PPh}_{3}$ dissociate more rapidly than $\mathrm{P}\left(\mathrm{OCH}_{2}\right)_{3} \mathrm{CEt}$.

Calculations: Bicyclic Phosphite $\pi$-Acidity. To further understand the bonding between 1 and transition metals, density functional theory (DFT) calculations were carried out to compare bonding of 1 to $\mathrm{P}(\mathrm{OMe})_{3}, \mathrm{P}\left(\mathrm{OCH}_{2}\right)_{3} \mathrm{CEt}$, and $\mathrm{PF}_{3}$. The role of the $\mathrm{P} X(\mathrm{X}=\mathrm{O}, \mathrm{C}$, halide, etc. $) \sigma^{*}$ orbitals in 


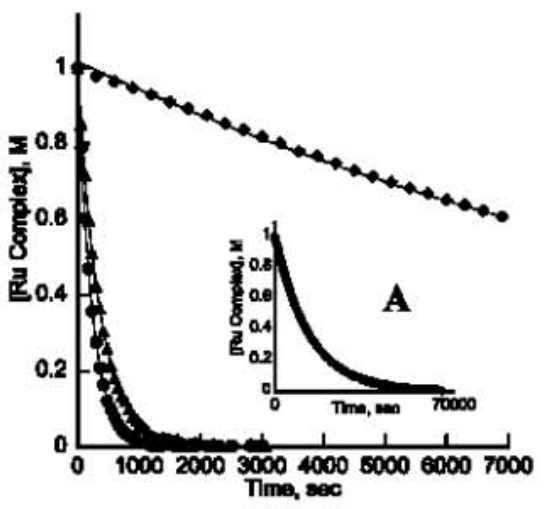

Figure 4. Representative kinetic plots for the exchange reaction of $\mathrm{L}$ in ( $\eta^{6}$-p-cymene $) \mathrm{Ru}(\mathrm{L}) \mathrm{Cl}_{2}$ complexes with $\mathrm{P}(\mathrm{OMe})_{3}$ (40 equiv relevant to concentration of $\mathrm{Ru}$ complex) in $\mathrm{CDCl}_{3}$ at $60 \mathrm{C}[\mathrm{L}=$

$\mathrm{P}\left(\mathrm{OCH}_{2}\right)_{2}\left(\mathrm{OCCH}_{3}\right)(13)\left[k_{\text {obs }}=0.0030(1) \mathrm{s}^{1}, \mathrm{R}^{2}=0.99\right], \quad \mathrm{PPh}_{3}$ (15) $\left.\left[k_{\text {obs }}=0.0045(3) \mathrm{s}^{1}, R^{2}=0.99\right)\right], \quad \mathrm{P}\left(\mathrm{OCH}_{2}\right)_{3} \mathrm{CEt}(12)\left[k_{\text {obs }}=\right.$ $0.000085(6) \mathrm{s}^{1}, R^{2}=0.99$ ]. Plot $\mathrm{A}$ shows the entire plot for the exchange reaction with $\mathrm{L}=\mathrm{P}\left(\mathrm{OCH}_{2}\right)_{3} \mathrm{CEt}$ (12).

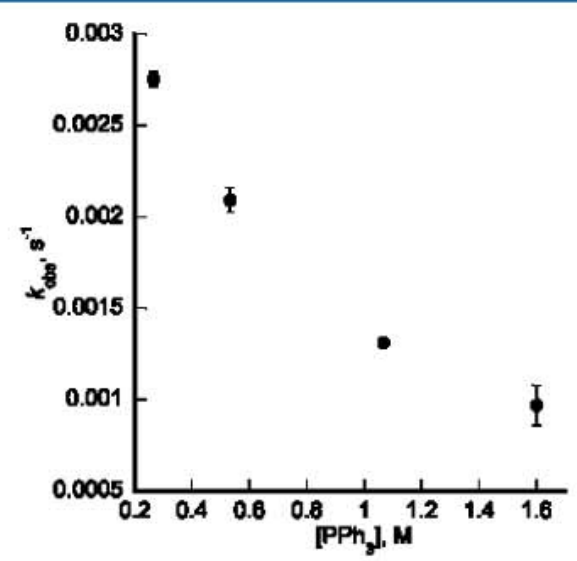

Figure 5. Plot of $k_{\text {obs }}$ versus concentration of $\mathrm{PPh}_{3}$ for the exchange of $\mathrm{PPh}_{3}$ with $\mathrm{P}(\mathrm{OMe})_{3}$ upon reaction of $\left(\eta^{6}-p\right.$-cymene $) \mathrm{Ru}\left(\mathrm{PPh}_{3}\right) \mathrm{Cl}_{2}$ (15) with excess $\mathrm{P}(\mathrm{OMe})_{3}$ in $\mathrm{CDCl}_{3}$ at $60 \mathrm{C}$.

$\pi$-acidity of phosphorus ligands has been documented. ${ }^{9,50,51}$ The energies of the $\mathrm{PX}_{3} \sigma^{*}$ orbitals are a function of the substituent $\mathrm{X}$ as well as the X P X bond angle. ${ }^{1,9}$ Smaller $\mathrm{X}$ $\mathrm{P} \quad \mathrm{X}$ angles are suggested to result in better $\pi$-acceptor ligands as the lowest unoccupied molecular orbitals (LUMOs) are lower in energy because of the reduced overlap between the 3 p phosphorus orbitals with $\sigma$-orbitals of the $\mathrm{X}$ substituents. Thus, the decreased $\mathrm{O} \mathrm{P} O$ bond angles of bicyclic phosphites that result from the cyclic structure are expected to decrease the energy of the $\sigma^{*}$ orbitals and, as a result, enhance $\pi$ acidity.

Structures were optimized for a linear gold(I) complex $[\mathrm{AuCl}(\mathrm{L})]$ and for the free ligand $\mathrm{L}$ where $\mathrm{L}=1, \mathrm{P}(\mathrm{OMe})_{3}$, $\mathrm{P}\left(\mathrm{OCH}_{2}\right)_{3} \mathrm{CEt}$, or $\mathrm{PF}_{3}$. $\mathrm{AuCl}(\mathrm{L})$ is an established organometallic fragment used by Fey et al. to parametrize ligand electronic and steric effects. ${ }^{52}$ While the experimental studies herein are focused on $\mathrm{Ru}(\mathrm{II})$, the $\mathrm{d}^{10}$ configuration of the $\mathrm{Au}(\mathrm{I})$ complex allowed for easier delineation of $\sigma$-donor and $\pi$-acceptor electronic effects without steric influence from cis ligands. The free ligand highest occupied molecular orbital (HOMO) and LUMO energies ( $E_{\text {HOMO }}$ and $E_{\text {LUMO }}$ ) are given in Table 5, along with the Au P bond length and

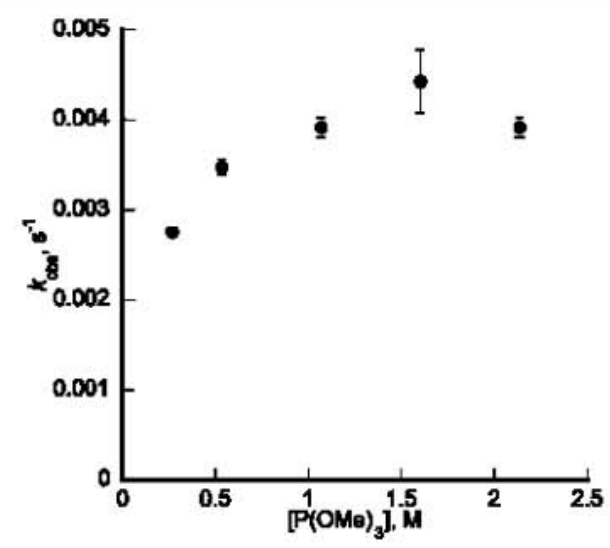

Figure 6. Plot of $k_{\text {obs }}$ versus concentration of $\mathrm{P}(\mathrm{OMe})_{3}$ for the exchange of $\mathrm{PPh}_{3}$ with $\mathrm{P}(\mathrm{OMe})_{3}$ upon reaction of $\left(\eta^{6}-p\right.$-cymene $) \mathrm{Ru}$ $\left(\mathrm{PPh}_{3}\right) \mathrm{Cl}_{2}(15)$ with excess $\mathrm{P}(\mathrm{OMe})_{3}$ in $\mathrm{CDCl}_{3}$ at $60 \mathrm{C}$.

Scheme 2. Proposed Mechanism for Exchange Reaction of $\mathrm{L}$ with $\mathrm{P}(\mathrm{OMe})_{3}$ to Form $\left(\eta^{6}-p\right.$-cymene $) \mathrm{Ru}\left[\mathrm{P}(\mathrm{OMe})_{3}\right] \mathrm{Cl}_{2}$ in $\mathrm{CDCl}_{3}$ at $60 \mathrm{C}$

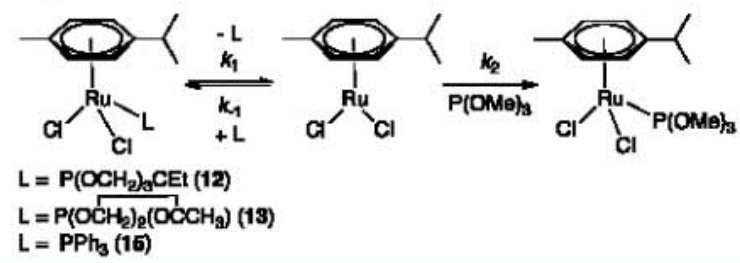

phosphine substituent angles $\left(\begin{array}{llll}X & P & X\end{array}\right)$ from the $[\mathrm{AuCl}(\mathrm{L})]$ complexes.

Care was taken when modeling the conformation of $\mathrm{P}(\mathrm{OMe})_{3},{ }^{53}$ with the lowest energy conformers in low and high coordinate compounds investigated $\left(\mathrm{ag}^{+} \mathrm{g}^{+}\right.$and $\mathrm{agg}^{+}$ respectively), as well as the most similar $\mathrm{P}(\mathrm{OMe})_{3}$ conformation to 1 , where the OMe groups are all anti to the metal phosphorus bond ( $a a$ a) (Scheme 3). Consideration of conformations is important to ensure that possible anomeric effects are not neglected, ${ }^{54}$ as delocalization of the phosphorus lone pair into an $\mathrm{O} C \sigma^{*}$ orbital is known to be more favorable if the substituent has an anti configuration. ${ }^{55}$ The anomeric effect is lessened when the phosphite is coordinated to a metal center. $^{53}$

The descriptor $E_{\text {Lumo }}$ has been shown in Ligand Knowledge Base research to be related to the $\pi$-accepting character of a phosphorus ligand. ${ }^{52}$ As the results in Table 5 indicate, the energy of the LUMO ( $\left.E_{\text {LUMO }}\right)$ is significantly lower for $\mathbf{1}$ compared to that of the $\mathrm{P}(\mathrm{OMe})_{3}$ conformers, which directly correlates to the size of the $\mathrm{O} P \mathrm{P}$ angle. Likewise, the $E_{\text {Lumo }}$ of $\mathbf{1}$ is lower than that calculated for $\mathrm{P}\left(\mathrm{OCH}_{2}\right)_{3} \mathrm{CEt}$. The calculated $\mathrm{X} \quad \mathrm{P} \quad \mathrm{X}$ angles of 1 and $\mathrm{PF}_{3}$ are smallest, supporting the hypothesis that small $\mathrm{X} P \mathrm{P}$ angles lower the $E_{\mathrm{Lumo}}$ and thereby increase the ligand s $\pi$-acidity. The LUMO energy for $\mathrm{PF}_{3}$ is likely lower than that for $\mathbf{1}$ as a result of the more strongly withdrawing fluorine substituents of $\mathrm{PF}_{3}$. Structural parameters from the linear $\mathrm{Au}(\mathrm{I})$ calculations also show a clear correlation between the $E_{\mathrm{LUMO}}$, $\mathrm{Au} \mathrm{P}$ bond lengths, and the $\mathrm{NBO}$ analysis for the $3 \mathrm{~s}$ character of $\mathrm{P}$, all given in Table 5 . For the latter, 1 has more s character for the phosphorus lone pair than the other phosphite ligands studied, with $\mathrm{PF}_{3}$, as expected, exhibiting the largest $\mathrm{s}$ character as it is the best $\pi$-acceptor. Again for 1 , Au P is shorter $(0.02 \AA)$ than that observed in 
Table 5. Data from DFT Calculations of $\mathrm{P}\left(\mathrm{OCH}_{2}\right)_{2}\left(\mathrm{OCCH}_{3}\right)(1), \mathrm{P}(\mathrm{OMe})_{3}, \mathrm{P}\left(\mathrm{OCH}_{2}\right)_{3} \mathrm{CEt}$, and $\mathrm{PF}_{3}$

\begin{tabular}{|c|c|c|c|c|c|c|c|}
\hline ligand & conformation & $\begin{array}{c}E_{\text {Hомо }} \\
\text { [hartree] }\end{array}$ & $\begin{array}{c}E_{\text {Lumo }} \\
\text { [hartree] }\end{array}$ & $\mathrm{Au}_{[A]} \mathrm{P}$ & NBO 3s character on $P$ & $\underset{[\mathrm{deg}]}{\operatorname{average} \mathrm{X}} \quad \mathrm{X}$ & $\begin{array}{l}\text { relative free energy } \\
{\left[\begin{array}{l}\text { kcal mol } \\
\text { 1] }\end{array}\right.}\end{array}$ \\
\hline $\mathrm{P}\left(\mathrm{OCH}_{2}\right)_{2}\left(\mathrm{OCCH}_{3}\right)(1)$ & & 0.2343 & 0.0428 & 2.21 & 1.564 & 97.4 & \\
\hline $\mathrm{P}(\mathrm{OMe})_{3}$ & $\mathrm{ag}^{+} \mathrm{g}^{+}$ & 0.2190 & 0.0235 & 2.24 & 1.541 & 102.5 & 0.0 \\
\hline $\mathrm{P}(\mathrm{OMe})_{3}$ & $\mathrm{agg}^{+}$ & 0.2230 & 0.0241 & 2.24 & 1.544 & 102.7 & 1.0 \\
\hline $\mathrm{P}(\mathrm{OMe})_{3}$ & $a a$ & 0.2215 & 0.0118 & 2.23 & 1.538 & 105.6 & 7.6 \\
\hline $\mathrm{P}\left(\mathrm{OCH}_{2}\right)_{3} \mathrm{CEt}$ & & 0.2296 & 0.0196 & 2.22 & 1.531 & 102.2 & \\
\hline $\mathrm{PF}_{3}$ & & 0.3089 & 0.0709 & 2.20 & 1.652 & 99.5 & \\
\hline
\end{tabular}

Scheme 3. Orientations of $\mathrm{P}(\mathrm{OMe})_{3}$ Ligand Defined by the Torsion Au P O Me (Viewed along the Au P Bond) That Were Modeled Using DFT Calculations

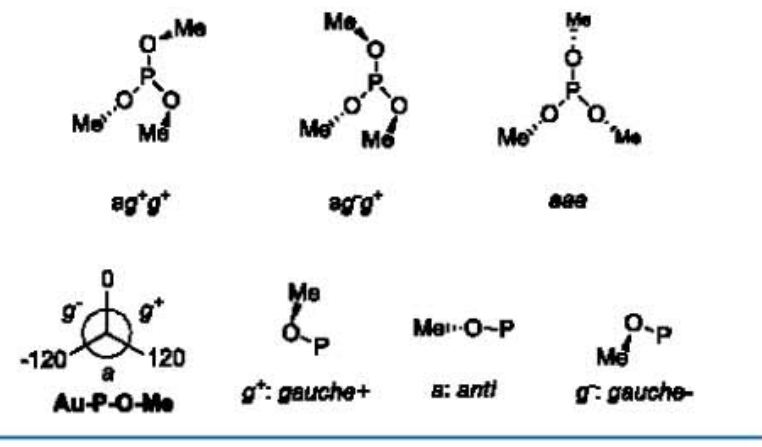

the equivalent $\mathrm{P}(\mathrm{OMe})_{3}$ and $\mathrm{P}\left(\mathrm{OCH}_{2}\right)_{3}$ CEt complexes, further corroborating a higher $\pi$-acidity character for phosphite $\mathbf{1}$ than the others included in this study and placing it below $\mathrm{PF}_{3}$ on the $\pi$-acidity scale.

\section{CONCLUSIONS}

Crystallographic and cyclic voltammetry data have been used to demarcate the properties of 1 compared with other phosphine and phosphite ligands, as well as carbon monoxide, using three types of ruthenium complexes, $\mathrm{TpRu}(\mathrm{L})\left(\mathrm{PPh}_{3}\right) \mathrm{Cl},\left(\eta^{6}-\mathrm{C}_{6} \mathrm{H}_{6}\right)$ $\mathrm{Ru}(\mathrm{L}) \mathrm{Cl}_{2}$, and $\left(\eta^{6}-p\right.$-cymene $) \mathrm{Ru}(\mathrm{L}) \mathrm{Cl}_{2}$. Data clearly indicate that the formal removal of one methylene group from the bicyclic phosphite $\mathrm{P}\left(\mathrm{OCH}_{2}\right)_{3} \mathrm{CEt}$, which gives phosphite 1, results in a decrease in electron-density at the metal center. For all three types of $\mathrm{Ru}$ complexes, redox potentials with $\mathbf{1}$ in the coordination sphere are shifted positive by 0.11 to $0.13 \mathrm{~V}$ compared to analogous systems with $\mathrm{P}\left(\mathrm{OCH}_{2}\right)_{3} \mathrm{CEt}$. Furthermore, when $\mathrm{L}=1$, the metal is less electron-rich (as determined by cyclic voltammetry) than metals coordinated by all other phosphorus ligands studied including $\mathrm{P}(\mathrm{OMe})_{3}, \mathrm{PMe}_{3}$, $\mathrm{PPh}_{3}$, and $\mathrm{P}\left(\mathrm{OCH}_{2}\right)_{3} \mathrm{CEt}$. It can be concluded that 1 is overall more weakly donating than the acyclic phosphite $\mathrm{P}(\mathrm{OMe})_{3}$. The source of these differences is more difficult to pinpoint. Verkade et al. have rationalized differences in basicity of cyclic vs acyclic phosphites (and related ligands) with the hinge effect, ${ }^{3,23} 26$ which involves differences in $\mathrm{O} \mathrm{P} \pi$-overlap as function of $\mathrm{O} \quad \mathrm{P} \quad \mathrm{O}$ and $\mathrm{P} \quad \mathrm{O} \quad \mathrm{C}$ bond angles (see above). In addition, differences in $\mathrm{O} \mathrm{P} O$ bond angles (for cyclic vs acyclic phosphites) might impact O P $\sigma$-overlap and, hence, the energy of $\mathrm{P} \mathrm{O} \sigma^{*}$ orbitals, which could influence ligand $\pi$-acidity. DFT calculations are consistent with this suggestion and indicate a lower energy LUMO for 1 compared to $\mathrm{P}(\mathrm{OMe})_{3}$ and $\mathrm{P}\left(\mathrm{OCH}_{2}\right)_{3} \mathrm{CEt}$.

\section{EXPERIMENTAL SECTION}

General Methods. Unless otherwise noted, all synthetic procedures were performed under anaerobic conditions in a nitrogen-filled glovebox or by using standard Schlenk techniques. Glovebox purity was maintained by periodic nitrogen purges and was monitored by an oxygen analyzer $\left[\mathrm{O}_{2}(\mathrm{~g})<15 \mathrm{ppm}\right.$ for all reactions $]$. Tetrahydrofuran was dried by distillation from sodium/benzophenone. Pentane was distilled over $\mathrm{P}_{2} \mathrm{O}_{5}$. Acetonitrile and diethyl ether were dried by distillation from $\mathrm{CaH}_{2}$. Hexanes, benzene, and methylene chloride were purified by passage through a column of activated alumina. Benzene- $d_{6}$, acetonitrile- $d_{3}$, methylene chloride- $d_{2}$, and chloroform- $d_{1}$ were stored under a $\mathrm{N}_{2}$ atmosphere over $4 \AA$ molecular sieves. ${ }^{1} \mathrm{H}$ NMR spectra were recorded on a Varian Mercury 300 or $500 \mathrm{MHz}$ spectrometer, and ${ }^{13} \mathrm{C}$ NMR spectra were recorded on a Varian Mercury $500 \mathrm{MHz}$ spectrometer (operating frequency $125 \mathrm{MHz}$ ). All ${ }^{1} \mathrm{H}$ and ${ }^{13} \mathrm{C}$ NMR spectra are referenced against residual proton signals ( ${ }^{1} \mathrm{H}$ NMR) or the ${ }^{13} \mathrm{C}$ resonances of the deuterated solvent $\left({ }^{13} \mathrm{C}\right.$ NMR). ${ }^{31} \mathrm{P}$ NMR spectra were obtained on a Varian $300 \mathrm{MHz}$ (operating frequency $121 \mathrm{MHz}$ ) spectrometer and referenced against an extemal standard of $\mathrm{H}_{3} \mathrm{PO}_{4}(\delta=0)$. Resonances due to the Tp ligand in ${ }^{1} \mathrm{H}$ NMR spectra are listed by chemical shift and multiplicity only (all coupling constants for the Tp ligand are $2 \mathrm{~Hz}$ ).

Electrochemical experiments were performed under a nitrogen atmosphere using a BAS Epsilon Potentiostat. Cyclic voltammograms were recorded in $\mathrm{NCCH}_{3}$ using a standard three electrode cell from

1700 to $1700 \mathrm{mV}$ at $100 \mathrm{mV} / \mathrm{s}$ [with the exception of $\left(\eta^{6}-\mathrm{C}_{6} \mathrm{H}_{6}\right) \mathrm{Ru}(\mathrm{CO}) \mathrm{Cl}_{2}$, which was scanned from 1700 to $2500 \mathrm{mV}$ at a scan rate of $100 \mathrm{mV} / \mathrm{s}$ ] with a glassy carbon working electrode and tetrabutylammonium hexafluorophosphate as electrolyte. All potentials are reported versus NHE (normal hydrogen electrode) using ferrocene as the internal standard.

High-resolution electrospray ionization mass spectrometry (ESIMS) analyses were obtained on a Bruker BioTOF-Q spectrometer at the University of Richmond. Samples were dissolved in acetonitrile then mixed $3: 1$ with $0.1 \mathrm{M}$ aqueous sodium trifluoroacetate (NaTFA) using $\left[\mathrm{Na}(\mathrm{NaTFA})_{x}\right]^{+}$clusters as an internal standard. These data are reported using the most intense peaks from the isotopic envelope for $[\mathrm{M}+\mathrm{Na}]^{+}$. The data are listed as $\mathrm{m} / z$ with the intensity relative to the most abundant peak of the isotopic envelope given in parentheses for both the calculated and the observed peaks. The difference between calculated and observed peaks is reported in ppm. In all cases, observed isotopic envelopes were consistent with the composition reported.

The preparation, isolation, and characterization of $\mathrm{TpRu}[\mathrm{P}$. $\left.\left(\mathrm{OCH}_{2}\right)_{3} \mathrm{CEt}\right]\left(\mathrm{PPh}_{3}\right) \mathrm{Cl}(3),{ }^{31} \mathrm{TpRu}\left(\mathrm{PMe}_{3}\right)\left(\mathrm{PPh}_{3}\right) \mathrm{Cl}(4),{ }^{38}\left(\eta^{6}-\right.$ $\left.\mathrm{C}_{6} \mathrm{H}_{6}\right) \mathrm{Ru}(\mathrm{CO}) \mathrm{Cl}_{2}(11),{ }^{39}\left(\eta^{6}-\mathrm{C}_{6} \mathrm{H}_{6}\right) \mathrm{Ru}\left(\mathrm{PPh}_{3}\right) \mathrm{Cl}_{2}(6),{ }^{40}$ and $\left(\eta^{6}-\right.$ $\left.\mathrm{C}_{6} \mathrm{H}_{6}\right) \mathrm{Ru}\left[\mathrm{P}(\mathrm{OMe})_{3}\right] \mathrm{Cl}(7)^{40}$ have been previously reported. $\mathrm{P}$ $\left(\mathrm{OCH}_{2}\right)_{3} \mathrm{CEt}$ was obtained from a commercial source and purified by reconstitution in hexanes followed by filtration through Celite. The filtrate was concentrated to dryness to yield pure material.

Calculations. DFT calculations were performed using the standard Becke-Perdew (BP86) density functional ${ }^{56}{ }^{60}$ in conjunction with the double- $\zeta 6-31+\mathrm{G}(\mathrm{d})$ basis set for all atoms excluding gold, for which the Los Alamos National Laboratory LANL2DZ ${ }^{61}$ basis set, augmented by diffuse and contracted $\mathrm{f}$ functions taken from Pyyko and Mendizabal ${ }^{62}$ and the $6 \mathrm{p}$ functions of Couty and Hall, ${ }^{63}$ was 
employed. All calculations were performed using the Gaussian 09 suite of programs. ${ }^{64}$

$\mathrm{C}\left(\mathrm{CH}_{3}\right)(\mathrm{OH})\left(\mathrm{CH}_{2} \mathrm{OH}\right)_{2}$. The synthesis of $\mathrm{C}\left(\mathrm{CH}_{3}\right)(\mathrm{OH})\left(\mathrm{CH}_{2} \mathrm{OH}\right)_{2}$ has been previously reported. ${ }^{36}$ We used an alternate procedure. The reaction was performed in a vented hood. $\mathrm{H}_{2} \mathrm{O}_{2}(30 \%, 6.82 \mathrm{~mL}$, $0.0662 \mathrm{~mol})$ was added to formic acid $(88 \%, 27.8 \mathrm{~mL}, 0.648 \mathrm{~mol})$, and the mixture was stirred at room temperature for $5 \mathrm{~min}$. The flask was placed in an ice bath, and 2-methyl-2-propen-1-ol $(4.0 \mathrm{~mL}, 0.047 \mathrm{~mol})$ was added slowly using an addition funnel. The reaction was heated at $40 \mathrm{C}$ for $1 \mathrm{~h}$. The solution was allowed to cool to room temperature. After $16 \mathrm{~h}$ at room temperature, the solution was concentrated in vacuo, and the residual oil was cooled in an ice bath and treated dropwise with $10 \mathrm{~mL}$ of cold $\mathrm{NaOH}(13.3 \mathrm{M})$. The resulting mixture was heated for $1 \mathrm{~h}$ at $40 \mathrm{C}$, which resulted in a yellow solution. After the addition of acetone $(50 \mathrm{~mL})$, the top layer was removed using a pipet. The acetone addition/extraction was repeated three times, and all extractions were combined. The combined fractions were concentrated under reduced pressure. The remaining pale yellow viscous oil was dissolved in a minimal amount of methanol, and diethyl ether was added to induce precipitation. The mixture was filtered using a fine porosity frit, and the solid was discarded. This step was repeated multiple times until no precipitate was observed upon the addition of diethyl ether. The filtrates were combined and concentrated in vacuo to give a brownish-yellow oil. The oil was purified by column chromatography on silica using $1: 2$ methanol/ethyl acetate as eluent. The solution was concentrated to dryness to yield a brownish-yellow oil $(2.634 \mathrm{~g}, 84 \%)$. The sample was dried by azeotropic distillation in benzene. ${ }^{1} \mathrm{H}$ NMR $\left(\mathrm{D}_{2} \mathrm{O}, 300 \mathrm{MHz}, \delta\right) 3.47\left(\mathrm{~s}, 4 \mathrm{H}, \mathrm{CH}_{2}\right), 1.13(\mathrm{~s}, 3 \mathrm{H}$, $\left.\mathrm{CH}_{3}\right),{ }^{13} \mathrm{C}$ NMR $\left(125 \mathrm{MHz}, \mathrm{CD}_{3} \mathrm{OD}, \delta\right) 73.8,67.6$ (both s, $\mathrm{C}$ and $\left.\mathrm{CH}_{2}\right), 21.3\left(\mathrm{~s}, \mathrm{CH}_{3}\right)$.

$\mathrm{P}\left(\mathrm{OCH}_{2}\right)_{2}\left(\mathrm{OCCH}_{3}\right)(1)$. The synthesis of $\mathrm{P}\left(\mathrm{OCH}_{2}\right)_{2}\left(\mathrm{OCCH}_{3}\right)$ has been previously reported. ${ }^{33}$ We used a modified procedure. $\mathrm{C}\left(\mathrm{CH}_{3}\right)$ $(\mathrm{OH})\left(\mathrm{CH}_{2} \mathrm{OH}\right)_{2}(1.032 \mathrm{~g}, 9.725 \mathrm{mmol})$ was added to benzene (200 $\mathrm{mL})$ in a $400 \mathrm{~mL}$ beaker. $\mathrm{NaH}(0.695 \mathrm{~g}, 29.0 \mathrm{mmol})$ was added to the reaction vessel, and the reaction mixture was stirred at room temperature for $1.25 \mathrm{~h} . \mathrm{PCl}_{3}(775 \mu \mathrm{L}, 8.89 \mathrm{mmol})$ was added slowly via syringe, and the reaction was stirred at room temperature overnight. The heterogeneous mixture was filtered through a fine porosity frit. Attempts to isolate pure 1 resulted in decomposition. Thus, for coordination to $\mathrm{Ru}, \mathbf{1}$ was generated as described above and added to the Ru precursor without isolation. ${ }^{31} \mathrm{P}\left\{{ }^{1} \mathrm{H}\right\}$ NMR (121 $\left.\mathrm{MHz}, \mathrm{C}_{6} \mathrm{D}_{6}, \delta\right): 115.5$.

$\mathrm{TpRu}\left[\mathrm{P}\left(\mathrm{OCH}_{2}\right)_{2}\left(\mathrm{OCCH}_{3}\right)\right]\left(\mathrm{PPh}_{3}\right) \mathrm{Cl}$ (2). A benzene solution of 1 $(150 \mathrm{~mL}, 2.98 \mathrm{mmol})$ was added to $\mathrm{TpRu}\left(\mathrm{PPh}_{3}\right)_{2} \mathrm{Cl}(0.510 \mathrm{~g}, 0.564 \mathrm{mmol})$. The solution was refluxed for $3 \mathrm{~h}$ to give a bright yellow solution. The solution was filtered through Celite, and the volatiles were removed from the filtrate in vacuo. The resulting solid was dissolved in minimal THF. Hexanes were added to induce precipitation of a yellow solid, which was collected on a fine porosity frit and dried in vacuo. The solid was dissolved in $\mathrm{CH}_{2} \mathrm{Cl}_{2}$ and loaded onto a silica column. The column was washed with hexanes, and the eluent was discarded. The column was then washed with $\mathrm{Et}_{2} \mathrm{O}$. The eluent was collected and reduced in vacuo to $2 \mathrm{~mL}$. Hexanes were added to induce precipitation of a yellow solid, which was collected on a fine porosity frit and dried in vacuo ( $0.0933 \mathrm{~g}, 19.5 \%$ yield). Crystals of 2 were obtained by slow evaporation of a $\mathrm{CH}_{2} \mathrm{Cl}_{2}$ solution layered with hexanes. ${ }^{1} \mathrm{H}$ NMR ( $500 \mathrm{MHz}, \mathrm{CDCl}_{3}, \delta$ ): $8.15,7.65,7.63,7.52$ (each a d, each $1 \mathrm{H}, \mathrm{Tp} 3$ and 5 ), 7.387 .15 (overlapping $\left.\mathrm{ms}, 15 \mathrm{H}, \mathrm{P}\left(\mathrm{C}_{6} \mathrm{H}_{5}\right)_{3}\right), 6.91$, 6.72 (each a d, each $1 \mathrm{H}, \mathrm{Tp} 3$ and 5$), 6.09\left(\mathrm{dt}, 1 \mathrm{H},{ }^{5} J_{\mathrm{HP}}=1.0 \mathrm{~Hz}, \mathrm{Tp} 4\right)$, $5.80\left(\mathrm{dt}, 1 \mathrm{H},{ }^{5} /_{\mathrm{HP}}=1.3 \mathrm{~Hz}, \mathrm{Tp} 4\right), 5.75(\mathrm{t}, 1 \mathrm{H}, \mathrm{Tp} 4), 3.93(\mathrm{dd}, 2 \mathrm{H}$, ${ }^{2} J_{\mathrm{HH}}=8.0 \mathrm{~Hz},{ }^{3} J_{\mathrm{HP}}=8.0 \mathrm{~Hz}, \mathrm{P}\left(\mathrm{OCH}_{2}\right)_{2}\left(\mathrm{OCCH}_{3}\right)$; Note: assignment of coupling constants was based on decoupling experiments), 3.50 (ddd, $\left.1 \mathrm{H},{ }^{2} J_{\mathrm{HH}}=8.0 \mathrm{~Hz},{ }^{3} J_{\mathrm{HP}}=3.6 \mathrm{~Hz},{ }^{4} J_{\mathrm{HH}}=1.4 \mathrm{~Hz}, \mathrm{P}\left(\mathrm{OCH}_{2}\right)_{2}\left(\mathrm{OCCH}_{3}\right)\right)$, $3.45\left(\mathrm{ddd}, 1 \mathrm{H},{ }^{2} J_{\mathrm{HH}}=8.0 \mathrm{~Hz},{ }^{3} \mathrm{HP}_{\mathrm{HP}}=3.6 \mathrm{~Hz},{ }^{4} / \mathrm{HH}=1.4 \mathrm{~Hz}\right.$, $\left.\mathrm{P}\left(\mathrm{OCH}_{2}\right)_{2}\left(\mathrm{OCCH}_{3}\right)\right), 1.51\left(\mathrm{~s}, 3 \mathrm{H}, \mathrm{P}\left(\mathrm{OCH}_{2}\right)_{2}\left(\mathrm{OCCH}_{3}\right)\right) .{ }^{13} \mathrm{C}$ NMR (125 $\left.\mathrm{MHz} \mathrm{CDCl}_{3}, \delta\right): 148.2,145.3,143.9,136.4$ ( $\mathrm{Tp} 3$ or 5 position), $135.0\left(\mathrm{~d}, J_{\mathrm{CP}}=9.0 \mathrm{~Hz}\right.$, ortho or meta of $\left.\mathrm{PPh}_{3}\right), 134.7,134.5(\mathrm{Tp} 3$ or 5 or ipso of $\mathrm{PPh}_{3}$ with one singlet missing presumably because of coincidental overlap), 129.3 (para of $\left.\mathrm{PPh}_{3}\right), 127.4\left(\mathrm{~d}, J_{\mathrm{CP}}=9.0 \mathrm{~Hz}\right.$, ortho or meta of $\mathrm{PPh}_{3}$ ), 105.7, 105.5, 105.2 (Tp 4 position), 81.6 $\left[\mathrm{P}\left(\mathrm{OCH}_{2}\right)_{2}\left(\mathrm{OCCH}_{3}\right)\right], 74.974 .7$ (overlapping resonances, P$\left.\left(\mathrm{OCH}_{2}\right)_{2}\left(\mathrm{OCCH}_{3}\right)\right), 15.6\left(\mathrm{~d}, I_{\mathrm{CP}}=10 \mathrm{~Hz}, \mathrm{P}\left(\mathrm{OCH}_{2}\right)_{2}\left(\mathrm{OCCH}_{3}\right)\right)$. ${ }^{31} \mathrm{P}\left\{{ }^{1} \mathrm{H}\right\}$ NMR $\left(121 \mathrm{MHz}, \mathrm{CDCl}_{3}, \delta\right): 162.6\left(\mathrm{~d},{ }^{2} J_{\mathrm{PP}}=55 \mathrm{~Hz}\right.$, $\left.\mathrm{P}\left(\mathrm{OCH}_{2}\right)_{2}\left(\mathrm{OCCH}_{3}\right)\right), 44.8\left(\mathrm{~d},{ }^{2} J_{\mathrm{PP}}=55 \mathrm{~Hz}, \mathrm{PPh}_{3}\right) . \mathrm{CV}\left(\mathrm{NCCH}_{3}\right)$ : $E_{1 / 2}=1.08 \mathrm{~V} \mathrm{Ru}(\mathrm{III} / \mathrm{II})$. Anal. Calcd. for $\mathrm{C}_{22} \mathrm{H}_{35} \mathrm{BClN}_{6} \mathrm{O}_{3} \mathrm{P}_{2} \mathrm{Ru}$ $\mathrm{CH}_{2} \mathrm{Cl}_{2}$ [Note: repeated efforts to dry this sample did not remove residual solvent. Thus, one equivalent of dichloromethane (observed and quantified by ${ }^{\mathrm{H}} \mathrm{H}$ NMR spectroscopy) is included in elemental analysis calculations ]: C, 46.26; H, 4.12; N, 10.12. Found: C, 46.84; H, 4.19 ; N, 10.28 .

TpRu[P(OMe $\left.)_{3}\right]\left(\mathrm{PPh}_{3}\right) \mathrm{Cl} \quad$ (5). $\mathrm{TpRu}\left(\mathrm{PPh}_{3}\right)_{2} \mathrm{Cl} \quad(0.295 \mathrm{~g}, 0.338$ mmol) was added to $20 \mathrm{~mL}$ of $\mathrm{C}_{6} \mathrm{H}_{6}$ and $\mathrm{P}(\mathrm{OMe})_{3}(0.0460 \mathrm{~g}, 0.371$ $\mathrm{mmol}$ ) was added. The solution was refluxed for $3 \mathrm{~h}$ to give a bright yellow solution. The volatiles were removed in vacuo. The resulting solid was dissolved in minimal THF. Hexanes were added, and the solvent was reduced in vacuo to induce precipitation of a yellow solid, which was collected on a fine porosity frit and dried in vacuo $(0.0557$ g, 67.0\%). ${ }^{1} \mathrm{H}$ NMR $\left(300 \mathrm{MHz}, \mathrm{CDCl}_{3}, \delta\right) 8.12,7.65,7.58,7.56$ (each a d, each $1 \mathrm{H}, \mathrm{Tp} 3$ and 5), 7.417 .11 (overlapping $\mathrm{ms}, 15 \mathrm{H}$, $\left.\mathrm{P}\left(\mathrm{C}_{6} \mathrm{H}_{5}\right)_{3}\right), 6.83,6.66$ (each a d, each $1 \mathrm{H}, \mathrm{Tp} 3$ and 5 ), 6.13, 5.75, 5.70 (each a t, each $1 \mathrm{H}, \mathrm{Tp} 4), 3.24\left(\mathrm{~d},{ }^{3} / \mathrm{HP}=10.3 \mathrm{~Hz}, 9 \mathrm{H}, \mathrm{P}\left(\mathrm{OCH}_{3}\right)_{3}\right)$. ${ }^{13} \mathrm{C}$ NMR $\left(125 \mathrm{MHz}, \mathrm{CDCl}_{3}\right) \delta 148.0,144.8,144.1,136.2,135.5$, 135.2 (Tp 3 or 5 position), $134.9\left(\mathrm{~d}, J_{\mathrm{CP}}=9 \mathrm{~Hz}\right.$, ortho or meta of $\left.\mathrm{P}\left(\mathrm{C}_{6} \mathrm{H}_{5}\right)_{3}\right), 134.6$ (ipso of $\left.\mathrm{P}\left(\mathrm{C}_{6} \mathrm{H}_{5}\right)_{3}\right), 128.9$ (para of $\left.\mathrm{P}\left(\mathrm{C}_{6} \mathrm{H}_{5}\right)_{3}\right), 127.2$ $\left(\mathrm{d}, J_{\mathrm{CP}}=9 \mathrm{~Hz}\right.$, ortho or meta of $\left.\mathrm{P}\left(\mathrm{C}_{6} \mathrm{H}_{5}\right)_{3}\right), 105.2$ (coincidental overlap of two $\mathrm{Tp} 4$ position), 104.3 ( $\mathrm{Tp} 4$ position), $51.8\left(\mathrm{~d},{ }^{2} J_{\mathrm{CP}}=6.3 \mathrm{~Hz}\right.$, $\left.\mathrm{CH}_{3}\right) .{ }^{31} \mathrm{P}$ NMR $\left(121 \mathrm{MHz}, \mathrm{CDCl}_{3}, \delta\right): 145.9\left(\mathrm{~d},{ }^{2} J_{\mathrm{Pp}}=54 \mathrm{~Hz}\right.$, $\mathrm{P}(\mathrm{OMe})_{3}, 46.1\left(\mathrm{~d},{ }^{2} I_{\mathrm{PP}}=54 \mathrm{~Hz}, P \mathrm{Ph}_{3}\right) . \mathrm{CV}\left(\mathrm{NCCH}_{3}\right): E_{1 / 2}=0.88 \mathrm{~V}$ $\mathrm{Ru}(\mathrm{III} / \mathrm{II})$. HRMS: $[\mathrm{M}+\mathrm{Na}]^{+}$obsd (\%), calcd (\%), ppm: 756.091 (38), 756.08845 (31.1), 3.4; 757.09061 (50.3), 757.09029 (53), 0.4; 758.09062 (77), 758.08983 (78.8), 1; 759.08946 (100), 759.08712 (100), 3.1; $760.09086(56.8), 760.08976(49.2), 1.4 ; 761.08919$ (73.4), 761.08741 (72.6), 2.3; 762.09149 (26.1), 762.0891 (27.9), 3.1.

$\left(\eta^{6}-\mathrm{C}_{6} \mathrm{H}_{6}\right) \mathrm{Ru}\left(\mathrm{PPh}_{3}\right) \mathrm{Cl}_{2}(6)$. The synthesis and characterization of $\left(\eta \eta^{6}-\mathrm{C}_{6} \mathrm{H}_{6}\right) \mathrm{Ru}\left(\mathrm{PPh}_{3}\right) \mathrm{Cl}_{2}$ have been previously reported. ${ }^{40}{ }^{\mathrm{I}} \mathrm{H}$ NMR spectroscopy revealed pure material and was consistent with previously reported data. $\mathrm{CV}\left(\mathrm{NCCH}_{3}\right): E_{1 / 2}=1.31 \mathrm{~V} \mathrm{Ru}(\mathrm{III} / \mathrm{II}$ ) (quasireversible); $E_{\mathrm{p}, \mathrm{c}}=0.85 \mathrm{~V}$ and $1.07 \mathrm{~V}$ )

$\left(\eta^{6}-\mathrm{C}_{6} \mathrm{H}_{6}\right) \mathrm{Ru}\left[\mathrm{P}(\mathrm{OMe})_{3}\right] \mathrm{Cl}(7)$. The synthesis and characterization of $\left(\eta^{6}-\mathrm{C}_{6} \mathrm{H}_{6}\right) \mathrm{Ru}\left[\mathrm{P}(\mathrm{OMe})_{3}\right] \mathrm{Cl}_{2}$ have been previously reported. ${ }^{40}{ }^{1} \mathrm{H}$ NMR spectroscopy revealed clean material and was consistent with previously reported data. $\mathrm{CV}\left(\mathrm{NCCH}_{3}\right): E_{1 / 2}=1.30 \mathrm{~V} \mathrm{Ru}(\mathrm{III} / \mathrm{II})$ (quasi-reversible); $E_{\mathrm{p}, \mathrm{c}}=0.94 \mathrm{~V}(n=2)$.

$\left(\eta^{6}-\mathrm{C}_{6} \mathrm{H}_{6}\right) \mathrm{Ru}\left(\mathrm{PMe}_{3}\right) \mathrm{Cl}_{2}(8)$. The synthesis of $\left(\eta^{6}-\mathrm{C}_{6} \mathrm{H}_{6}\right) \mathrm{Ru}\left(\mathrm{PMe}_{3}\right)$ $\mathrm{Cl}_{2}$ has been previously reported. ${ }^{42}$ We used an alternate procedure. $\left[\left(\eta^{6}-\mathrm{C}_{6} \mathrm{H}_{6}\right) \mathrm{Ru}(\mathrm{Cl})(\mu-\mathrm{Cl})\right]_{2}(0.140 \mathrm{~g}, 0.280 \mathrm{mmol})$ was stirred in $\mathrm{CH}_{2} \mathrm{Cl}_{2}(30 \mathrm{~mL})$ at room temperature. $\mathrm{PMe}_{3}(0.0470 \mathrm{~g}, 0.616$ $\mathrm{mmol}$ ) was added slowly by syringe. The mixture was stirred at room temperature for $3 \mathrm{~h}$ during which time the heterogeneous mixture became a homogeneous red solution. The solution was filtered through a fine porosity frit. The filtrate was reduced in vacuo to 5 $\mathrm{mL}$. Hexanes were added to provide an orange precipitate. The mixture was filtered through a fine porosity fritted funnel. The solid was dried in vacuo to yield an orange solid $(0.153 \mathrm{~g}, 83.8 \%)$. Although complex 8 has been previously reported, NMR data were not provided. ${ }^{1} \mathrm{H}$ NMR $\left(500 \mathrm{MHz}, \mathrm{CDCl}_{3}, \delta\right): 5.58\left(\mathrm{~s}, 6 \mathrm{H}, \mathrm{C}_{6} \mathrm{H}_{6}\right), 1.65\left(\mathrm{~d}, 9 \mathrm{H},{ }^{2} \mathrm{H}_{\mathrm{HP}}=\right.$ $\left.11.4 \mathrm{~Hz}, \mathrm{CH}_{3}\right) .{ }^{13} \mathrm{C} \mathrm{NMR}\left(125 \mathrm{MHz}, \mathrm{CDCl}_{3}, \delta\right): 87.2\left(\mathrm{~s}, \mathrm{C}_{6} \mathrm{H}_{6}\right), 16.6$ $\left(\mathrm{d},{ }^{1} \mathrm{I}_{\mathrm{PC}}=34.1 \mathrm{~Hz}, \mathrm{CH}_{3}\right){ }^{31} \mathrm{P}\left\{{ }^{1} \mathrm{H}\right\} \mathrm{NMR}\left(121 \mathrm{MHz}, \mathrm{CDCl}_{3}, \delta\right): 7.5(\mathrm{~s}$, $\left.\mathrm{PMe}_{3}\right)$. CV $\left(\mathrm{NCCH}_{3}\right): E_{1 / 2}=1.19 \mathrm{~V} \mathrm{Ru}(\mathrm{III} / \mathrm{II})$ (quasi-reversible); $E_{\mathrm{p}, \mathrm{c}}=$ $1.25 \mathrm{~V}$.

$\left(\eta^{6}-\mathrm{C}_{6} \mathrm{H}_{6}\right) \mathrm{Ru}\left[\mathrm{P}\left(\mathrm{OCH}_{2}\right)_{3} \mathrm{CEt}\right] \mathrm{Cl}_{2}$ (9). P(OCH$)_{3} \mathrm{CEt}(0.248 \mathrm{~g}$, $1.53 \mathrm{mmol})$ and $\left[\left(\eta^{6}-\mathrm{C}_{6} \mathrm{H}_{6}\right) \mathrm{Ru}(\mathrm{Cl})(\mu-\mathrm{Cl})\right]_{2}(0.382 \mathrm{~g}, 0.764 \mathrm{mmol})$ were stirred in $\mathrm{CH}_{2} \mathrm{Cl}_{2}(50 \mathrm{~mL})$ at room temperature overnight to give a heterogeneous mixture. The solid was collected by filtration 
through a fine porosity frit, washed with $\mathrm{CH}_{2} \mathrm{Cl}_{2}$ and pentane, and dried in vacuo to yield a red solid $(0.601 \mathrm{~g}, 95.5 \%)$. ${ }^{1} \mathrm{H}$ NMR (500 $\left.\mathrm{MHz}, \mathrm{DMSO}-d_{6} \delta\right): 5.82\left(\mathrm{~s}, 6 \mathrm{H}, \mathrm{C}_{6} \mathrm{H}_{6}\right), 4.37\left(\mathrm{~d}, 6 \mathrm{H},{ }^{3} J_{\mathrm{HP}}=4.7 \mathrm{~Hz}\right.$, $\left.\mathrm{P}\left(\mathrm{OCH}_{2}\right)_{3} \mathrm{CCH}_{2} \mathrm{CH}_{3}\right), 1.24\left(\mathrm{q}, 2 \mathrm{H},{ }^{3} J_{\mathrm{HH}}=7.7 \mathrm{~Hz}, \quad \mathrm{CCH}_{2} \mathrm{CH}_{3}\right), 0.77$ $\left(\mathrm{t}, 3 \mathrm{H},{ }^{3} J_{\mathrm{HH}}=7.6 \mathrm{~Hz}, \quad \mathrm{CCH}_{2} \mathrm{CH}_{3}\right) \cdot{ }^{13} \mathrm{C}$ NMR $\left(125 \mathrm{MHz}\right.$, DMSO- $d_{6}$ $\delta): 90.0\left(\mathrm{~s}, \mathrm{C}_{6} \mathrm{H}_{6}\right), 87.6\left(\mathrm{~s}, \mathrm{P}\left(\mathrm{OCH}_{2}\right)_{3} \mathrm{CCH}_{2} \mathrm{CH}_{3}\right), 74.8\left(\mathrm{~s}, \mathrm{P}\left(\mathrm{OCH}_{2}\right)_{3}\right.$ $\left.\mathrm{CCH}_{2} \mathrm{CH}_{3}\right), 22.1\left(\mathrm{~s}, \mathrm{P}\left(\mathrm{OCH}_{2}\right)_{3} \mathrm{CCH}_{2} \mathrm{CH}_{3}\right), 6.9\left(\mathrm{~s}, \mathrm{P}\left(\mathrm{OCH}_{2}\right)_{3}-\right.$ $\left.\mathrm{CCH}_{2} \mathrm{CH}_{3}\right) .{ }^{31} \mathrm{P}\left\{{ }^{1} \mathrm{H}\right\} \quad \mathrm{NMR}\left(121 \mathrm{MHz}\right.$, DMSO-d $\left.d_{6}, \delta\right): 107.5$ (s, $\left.P\left(\mathrm{OCH}_{2}\right)_{3} \mathrm{CCH}_{2} \mathrm{CH}_{3}\right)$. CV $\left(\mathrm{NCCH}_{3}\right): E_{\mathrm{p}, \mathrm{a}}=1.39 \mathrm{~V} \mathrm{Ru}(\mathrm{III} / \mathrm{II})$; $E_{\mathrm{p}, c}=1.09 \mathrm{~V} \mathrm{Ru}(\mathrm{II} / \mathrm{I})$. Anal. Caled for $\mathrm{C}_{12} \mathrm{H}_{17} \mathrm{Cl}_{2} \mathrm{O}_{3} \mathrm{PRu}$ $\left(\mathrm{CH}_{2} \mathrm{Cl}_{2}\right)_{0.25}$ [Note: repeated efforts to dry this sample did not remove residual solvent. Thus, 0.25 equivalents of dichloromethane (observed and quantified by ${ }^{1} \mathrm{H}$ NMR spectroscopy) are included in elemental analysis calculations]: C, 33.94; H, 4.08. Found: C, 34.25; H, 4.18 .

$\left(\eta^{6}-\mathrm{C}_{6} \mathrm{H}_{6}\right) \mathrm{Ru}\left[\mathrm{P}\left(\mathrm{OCH}_{2}\right)_{2}\left(\mathrm{OCCH} \mathrm{CH}_{3}\right)\right] \mathrm{Cl}_{2}$ (11). Compound 1 [55 mL of 1 in $\left.\mathrm{C}_{6} \mathrm{H}_{6}(0.0054 \mathrm{M})\right]$ was added to $\left[\left(\eta^{6}-\mathrm{C}_{6} \mathrm{H}_{6}\right) \mathrm{Ru}(\mathrm{Cl})(\mu-\mathrm{Cl})\right]_{2}$ $(0.505 \mathrm{~g}, 1.01 \mathrm{mmol})$. The solution was stirred in $\mathrm{CH}_{2} \mathrm{Cl}_{2}(100 \mathrm{~mL})$ at room temperature for $2 \mathrm{~h}$ to give an orange solution. The mixture was filtered through a fine porosity frit. The filtrate was added to a $1 / 4 \mathrm{in}$. plug of silica gel on top of $1 / 4 \mathrm{in}$. of Celite and eluted with $\mathrm{CH}_{2} \mathrm{Cl}_{2}$. The volume of the eluent was reduced in vacuo to $3 \mathrm{~mL}$. Hexanes were added to the eluent to yield a red precipitate. The solution was filtered through a fine porosity frit and dried in vacuo to give a red solid $(0.102 \mathrm{~g}, 25 \%$ based on Ru dimer). Crystals of 4 were obtained by slow evaporation from a chloroform solution. ${ }^{1} \mathrm{H}$ NMR $(500 \mathrm{MHz}$, $\left.\mathrm{CD}_{2} \mathrm{Cl}_{2} \delta\right) 5.90\left(\mathrm{~s}, 6 \mathrm{H}, \mathrm{C}_{6} \mathrm{H}_{6}\right), 4.26\left(\mathrm{~m}, 2 \mathrm{H}, \mathrm{P}\left(\mathrm{OCH}_{2}\right)_{2}\left(\mathrm{OCCH}_{3}\right)\right)$, $3.84\left(\mathrm{~d}, 2 \mathrm{H},{ }^{2} \mathrm{HHH}_{\mathrm{HH}}=6.5 \mathrm{~Hz} \mathrm{CH}\right), 1.69\left(\mathrm{~s}, 3 \mathrm{H}, \mathrm{CH}_{3}\right) \cdot{ }^{13} \mathrm{C} \mathrm{NMR}(75$ $\left.\mathrm{MHz}, \mathrm{CDCl}_{3}, \delta\right): 91.5\left(\mathrm{~s}, \mathrm{C}_{6} \mathrm{H}_{6}\right), 83.3\left(\mathrm{~s}, \mathrm{P}\left(\mathrm{OCH}_{2}\right)_{2}\left(\mathrm{OCCH}_{3}\right)\right), 75.9$ $\left(\mathrm{d},{ }^{2} \mathrm{IPP}_{\mathrm{CP}}=5.4 \mathrm{~Hz}, \mathrm{P}\left(\mathrm{OCH}_{2}\right)_{2}\left(\mathrm{OCCH}_{3}\right)\right), 15.0\left(\mathrm{~s}, \mathrm{P}\left(\mathrm{OCH}_{2}\right)_{2}\left(\mathrm{OCCH}_{3}\right)\right)$. ${ }^{31} \mathrm{P}\left\{{ }^{\mathrm{I}} \mathrm{H}\right\} \mathrm{NMR}\left(121 \mathrm{MHz}, \mathrm{CD}_{2} \mathrm{Cl}_{2} \delta\right): 139.7 \mathrm{P}\left(\mathrm{OCH}_{2}\right)_{2}\left(\mathrm{OCCH}_{3}\right)$. HRMS: $[\mathrm{M}+\mathrm{Na}]^{+}$obsd $(\%)$, calcd (\%), ppm: $403.89292(36.8)$, 403.8932 (15.2), $0.7 ; 405.89292$ (36.8), 405.89274 (25.3), 0.4; 406.89271 (100), 406.8917 (100), 2.5; 407.89157 (36.8), 407.89134 (12.8), 0.6; 408.88907 (97.7), 408.89079 (28.8), $4.2 ; 409.89174$ (85.5), 409.8919 (84.2), $0.4 ; 410.88847$ (85.5), 410.88871 (84.2), 0.6. CV $\left(\mathrm{NCCH}_{3}\right): E_{\mathrm{p}, \mathrm{a}}=1.50 \mathrm{~V} \mathrm{Ru}$ (III/II); $E_{\mathrm{p}, \mathrm{c}}=0.99 \mathrm{~V}$ $\mathrm{Ru}(\mathrm{II} / \mathrm{I})$.

$\left.\left(\eta^{6} \text {-p-cymene) Ru[P(OCH}\right)_{3} \mathrm{CEt}\right] \mathrm{Cl}_{2}$ (12). The dimeric complex $\left[\left(\eta^{6}-p \text {-cymene }\right) \mathrm{Ru}(\mathrm{Cl})(\mu-\mathrm{Cl})\right]_{2}(0.102 \mathrm{~g}, 0.166 \mathrm{mmol})$ and $\mathrm{P}$ $\left(\mathrm{OCH}_{2}\right)_{3} \mathrm{CEt}(0.0690 \mathrm{~g}, 0.436 \mathrm{mmol})$ were combined in a roundbottom flask with $20 \mathrm{~mL}$ of $\mathrm{CH}_{2} \mathrm{Cl}_{2}$. The reaction mixture was stirred at room temperature for $1 \mathrm{~h}$. The total volume of the solution was reduced in vacuo to $2 \mathrm{~mL}$. Hexanes were added to yield a red-orange precipitate. The solid was collected by filtration through a fine porosity frit and dried in vacuo to yield a red-orange solid $(0.3830 \mathrm{~g}, 83 \%)$. ' $\mathrm{H}$ $\operatorname{NMR}\left(300 \mathrm{MHz}, \mathrm{CDCl}_{3}, \delta\right) 5.63\left(\mathrm{~d}, 2 \mathrm{H},{ }^{3} \mathrm{~J}_{\mathrm{HH}}=6.0 \mathrm{~Hz}, \mathrm{C}_{6} \mathrm{H}_{4}\right), 5.51$ $\left(\mathrm{d}, 2 \mathrm{H},{ }^{3} \mathrm{H}_{\mathrm{HH}}=6.0 \mathrm{~Hz}, \mathrm{C}_{6} \mathrm{H}_{4}\right), 4.37\left(\mathrm{~d}, 6 \mathrm{H},{ }^{3} \mathrm{JPP}_{\mathrm{HP}}=5.0 \mathrm{~Hz}, \mathrm{P}\left(\mathrm{OCH}_{2}\right)_{3}\right.$ $\left.\mathrm{CCH}_{2} \mathrm{CH}_{3}\right), 2.88\left(\right.$ sept, $1 \mathrm{H},{ }^{2} \mathrm{IHH}_{\mathrm{HH}}=7 \mathrm{~Hz},\left(\mathrm{CH}_{3} \mathrm{C}_{6} \mathrm{H}_{4}(\mathrm{CH})\left(\mathrm{CH}_{3}\right)_{2}\right)$, $2.16\left(\mathrm{~s}, 3 \mathrm{H}, \mathrm{C}_{6} \mathrm{H}_{4} \mathrm{CH}_{3}\right), 1.321 .15$ (overlapping $\mathrm{m} \mathrm{s}, 8 \mathrm{H}$, coincidental overlap of $\mathrm{P}\left(\mathrm{OCH}_{2}\right)_{3} \mathrm{CCH}_{2} \mathrm{CH}_{3}$ and $\left.\mathrm{C}_{6} \mathrm{H}_{4} \mathrm{CH}\left(\mathrm{CH}_{3}\right)_{2}\right), 0.84$ $\left(\mathrm{t}, 3 \mathrm{H},{ }^{3} / \mathrm{HH}=8 \mathrm{~Hz},\left(\mathrm{P}\left(\mathrm{OCH}_{2}\right)_{3} \mathrm{CCH}_{2} \mathrm{CH}_{3}\right) \cdot{ }^{13} \mathrm{C} \mathrm{NMR}(75 \mathrm{MHz}\right.$, $\left.\mathrm{CDCl}_{3}\right) \delta 108.9\left(\mathrm{~s}, \mathrm{C}_{6} \mathrm{H}_{4}\right), 103.3\left(\mathrm{~s}, \mathrm{C}_{6} \mathrm{H}_{4}\right), 90.1\left(\mathrm{~d},{ }^{2} J_{\mathrm{PC}}=7.1 \mathrm{~Hz}\right.$, $\left.\mathrm{C}_{6} \mathrm{H}_{4}\right), 89.3\left(\mathrm{~d},{ }^{2} J_{\mathrm{PC}}=6.0 \mathrm{~Hz}, \mathrm{C}_{6} \mathrm{H}_{4}\right), 75.5\left(\mathrm{~d},{ }^{2} J_{\mathrm{CP}}=7.6 \mathrm{~Hz}\right.$, $\left.\mathrm{P}\left(\mathrm{OCH}_{2}\right)_{3} \mathrm{CCH}_{2} \mathrm{CH}_{3}\right), 36.1\left({ }^{3} \mathrm{IPP}_{\mathrm{CP}}=32.2 \mathrm{~Hz}, \mathrm{P}\left(\mathrm{OCH}_{2}\right)_{3} \mathrm{CCH}_{2} \mathrm{CH}_{3}\right)$, $30.5\left(\mathrm{~s}, \mathrm{C}_{6} \mathrm{H}_{4}-\mathrm{CH}\left(\mathrm{CH}_{3}\right)_{2}\right), 23.4\left(\mathrm{~s}, \mathrm{P}\left(\mathrm{OCH}_{2}\right)_{3} \mathrm{CCH}_{2} \mathrm{CH}_{3}\right), 22.1\left(\mathrm{~s}, \mathrm{C}_{6} \mathrm{H}_{4}-\right.$ $\left.\left(\mathrm{CH}\left(\mathrm{CH}_{3}\right)_{2}\right)\right), 18.6\left(\mathrm{~s}, \mathrm{C}_{6} \mathrm{H}_{4}-\mathrm{CH}_{3}\right), 7.3\left(\mathrm{~s}, \mathrm{P}\left(\mathrm{OCH}_{2}\right)_{3} \mathrm{CCH}_{2} \mathrm{CH}_{3}\right)$. ${ }^{31} \mathrm{P}\left\{{ }^{1} \mathrm{H}\right\}$ NMR $\left(121 \mathrm{MHz}, \mathrm{CD}_{2} \mathrm{Cl}_{2}, \delta\right): 111.8\left(P\left(\mathrm{OCH}_{2}\right)_{2} \mathrm{CEt}\right)$. HRMS: $[\mathrm{M}+\mathrm{Na}]^{+}$obsd (\%), calcd (\%), ppm: $488.9858(37.6), 488.98503$ (32.9), $1.6 ; 489.98611$ (62.9), 489.98504 (42), 2.2; 490.98525 (100), 490.98445 (100), 1.6; 491.98534 (44.5), 491.98404 (32.9), 2.6; 492.9845 (96.7), 492.98449 (94.8), $0 ; 493.98643$ (85.5), 493.98554 (84.2), 1.8; 494.98312 (85.5), $494.98235(84.2)$, 1.6. CV $\left(\mathrm{NCCH}_{3}\right): E_{1 / 2}=1.30 \mathrm{~V} \mathrm{Ru}(\mathrm{III} / \mathrm{II})$ (quasi-reversible); $E_{\mathrm{p}, c}=1.23 \mathrm{~V} \mathrm{Ru}(\mathrm{II} / \mathrm{I})$.

$\left.\left(\eta^{6} \text {-p-cymene) Ru[P(OCH}\right)_{2}\left(\mathrm{OCCH}_{3}\right)\right] \mathrm{Cl}_{2}$ (13). A benzene solution of $1(0.570 \mathrm{~g}, 4.25 \mathrm{mmol})$ was added to $\left[\left(\eta^{6}-p\right.\right.$-cymene $) \mathrm{Ru}(\mathrm{Cl})$ $(\mu$-Cl $)]_{2}(0.369 \mathrm{~g}, 0.603 \mathrm{mmol})$ in $\mathrm{CH}_{2} \mathrm{Cl}_{2}(75 \mathrm{~mL})$. The solution was stirred at room temperature for $30 \mathrm{~min}$ to give an orange solution. The solvent volume was reduced in vacuo to $25 \mathrm{~mL}$. Hexanes were added to yield a red precipitate, which formed a red oil. The solution was filtered through Celite. The solid collected on Celite was eluted with $\mathrm{CH}_{2} \mathrm{Cl}_{2}$. The solvent was removed in vacuo. The resulting solid was washed with pentane. The solid was dried to yield a reddishorange solid $(0.489 \mathrm{~g}, 92.3 \%)$. This crude material was purified on an alumina column with $1: 1 \mathrm{CH}_{2} \mathrm{Cl}_{2} / \mathrm{THF}$ as eluent $(0.088 \mathrm{mg}, 20 \%)$. ${ }^{1} \mathrm{H}$ NMR $\left(300 \mathrm{MHz}, \mathrm{CDCl}_{3}, \delta\right) 5.76\left(\mathrm{~d}, 2 \mathrm{H}, \mathrm{C}_{6} \mathrm{H}_{4},{ }^{3} / \mathrm{HH}=5.9 \mathrm{~Hz}\right)$, $5.62\left(\mathrm{~d}, 2 \mathrm{H}, \mathrm{C}_{6} \mathrm{H}_{4},{ }^{3} \mathrm{HHH}_{\mathrm{HH}}=5.9 \mathrm{~Hz}\right), 4.22$ (apparent t, $2 \mathrm{H}$, $\left.\mathrm{P}\left(\mathrm{OCH}_{2}\right)_{2}\left(\mathrm{OCCH}_{3}\right),{ }^{2} J_{\mathrm{HH}}=8 \mathrm{~Hz}\right), 3.83\left(\mathrm{~d}, 2 \mathrm{H}, \mathrm{P}\left(\mathrm{OCH}_{2}\right)_{2}\left(\mathrm{OCCH}_{3}\right)\right.$ $\left.{ }^{2} J_{\mathrm{HH}}=7 \mathrm{~Hz}\right), 2.90\left(\right.$ sept, $1 \mathrm{H},\left(\mathrm{CH}_{3} \mathrm{C}_{6} \mathrm{H}_{4}(\mathrm{CH})\left(\mathrm{CH}_{3}\right)_{2}{ }^{3} J_{\mathrm{HH}}=7 \mathrm{~Hz}\right)$, $2.22\left(\mathrm{~s}, 3 \mathrm{H}, \mathrm{C}_{6} \mathrm{H}_{4} \mathrm{CH}_{3}\right), 1.68\left(\mathrm{~s}, 3 \mathrm{H}, \mathrm{P}\left(\mathrm{OCH}_{2}\right)_{2}\left(\mathrm{OCCH}_{3}\right)\right), 1.23$ $\left(\mathrm{d}, 6 \mathrm{H}, \mathrm{C}_{6} \mathrm{H}_{4} \mathrm{CH}\left(\mathrm{CH}_{3}\right)_{2},{ }_{\mathrm{HH}}=7 \mathrm{~Hz}\right) .{ }^{13} \mathrm{C} \mathrm{NMR}\left(75 \mathrm{MHz}, \mathrm{CDCl}_{3}\right.$, d) $110.0\left(\mathrm{~s}, \mathrm{C}_{6} \mathrm{H}_{4}\right), 106.2\left(\mathrm{~s}, \mathrm{C}_{6} \mathrm{H}_{4}\right), 90.5\left(\mathrm{C}_{6} \mathrm{H}_{4}\right), 90.4\left(\mathrm{C}_{6} \mathrm{H}_{4}\right)$, $90.1\left(\mathrm{C}_{6} \mathrm{H}_{4}\right), 90.1\left(\mathrm{C}_{6} \mathrm{H}_{4}\right), 82.9\left(\mathrm{P}\left(\mathrm{OCH}_{2}\right)_{2}\left(\mathrm{OCCH}_{3}\right)\right), 75.7(\mathrm{~s}$, $\left.\mathrm{P}\left(\mathrm{OCH}_{2}\right)_{2}\left(\mathrm{OCCH}_{3}\right)\right), 75.6\left(\mathrm{P}\left(\mathrm{OCH}_{2}\right)_{2}\left(\mathrm{OCCH}_{3}\right)\right), 30.9\left(\mathrm{C}_{6} \mathrm{H}_{4}-\right.$ $\left.\mathrm{CH}\left(\mathrm{CH}_{3}\right)_{2}\right), 22.3\left(\mathrm{~s}\right.$, symm. equivalent $\left.\mathrm{C}_{6} \mathrm{H}_{4} \mathrm{C}\left(\mathrm{CH}_{3}\right)_{2}\right), 18.8(\mathrm{~s}$, $\left.\mathrm{C}_{6} \mathrm{H}_{4}-\mathrm{CH}_{3}\right), 15.3\left(\mathrm{~d},{ }^{3} \mathrm{HH}_{\mathrm{HH}}=10.4 \mathrm{~Hz}, \mathrm{P}\left(\mathrm{OCH}_{2}\right)_{2}\left(\mathrm{OCCH}_{3}\right)\right) .{ }^{31} \mathrm{P}\left\{{ }^{1} \mathrm{H}\right\}$ NMR $\left(121 \mathrm{MHz}, \mathrm{CDCl}_{3} \delta\right): 143.6\left(\mathrm{~s}, \mathrm{P}\left(\mathrm{OCH}_{2}\right)_{2}\left(\mathrm{OCCH}_{3}\right)\right)$. HRMS: $[\mathrm{M}+\mathrm{Na}]^{+}$obsd (\%), calcd (\%), ppm: $460.95441(37.4), 460.95328$ (46.3), $2.5 ; 461.95477$ (63), 461.95265 (60.9), 4.6; 462.95389 (100), 462.95262 (100), 2.7; 463.95387 (42.9), 463.95148 (48.6), 5.2; 464.95316 (97.1), 464.95168 (91.8), 3.2; 465.95496 (85.5), 465.95309 (84.2), 4; 466.95174 (85.5), 466.95034 (84.2), 3. CV $\left(\mathrm{NCCH}_{3}\right)$ : $E_{1 / 2}=1.44 \mathrm{~V} \mathrm{Ru}(\mathrm{III} / \mathrm{II})$ (quasi-reversible); $E_{\mathrm{p}, \mathrm{c}}=1.05 \mathrm{~V}$.

$\left.\left(\eta^{6} \text {-p-cymene) Ru[P(OMe) }\right)_{3}\right] \mathrm{Cl}_{2}$ (14). The synthesis of complex 14 has been previously reported. ${ }^{47} \mathrm{We}$ used an alternate procedure, which is given below. $\left[\left(\eta^{6}-p \text {-cymene }\right) \mathrm{Ru}(\mathrm{Cl})(\mu \text {-Cl })\right]_{2}(0.0517 \mathrm{~g}, 0.0844 \mathrm{mmol})$ was stirred at room temperature in $\mathrm{CH}_{2} \mathrm{Cl}_{2}(15 \mathrm{~mL}) . \mathrm{P}(\mathrm{OMe})_{3}$ $(0.0232 \mathrm{~g}, 0.187 \mathrm{mmol})$ was added by syringe. The solution was stirred at room temperature for $2 \mathrm{~h}$ after which time the solution was reduced in vacuo to $3 \mathrm{~mL}$. Hexanes were added to yield an orange precipitate. The mixture was filtered through a fine porosity frit. The solid was washed with pentane and dried in vacuo to yield an orange solid $(0.0553 \mathrm{~g}, 76.1 \%$ yield $) .{ }^{1} \mathrm{H}$ NMR spectroscopy revealed clean material and was consistent with previously reported data. ${ }^{47} \mathrm{CV}\left(\mathrm{NCCH}_{3}\right)$ : $E_{1 / 2}=1.25 \mathrm{~V} \mathrm{Ru}\left(\mathrm{III} /\right.$ III) (quasi-reversible); $E_{\mathrm{p}, \mathrm{c}}=1.21 \mathrm{~V}$.

$\left(\eta^{6}-p\right.$-cymene) $\mathrm{Ru}\left(\mathrm{PPh}_{3}\right) \mathrm{Cl}_{2}$ (15). The synthesis of complex 15 has been previously reported. ${ }^{47} \mathrm{We}$ used an alternate procedure, which is given below. $\left[\left(\eta^{6}-p \text {-cymene }\right) \mathrm{Ru}(\mathrm{Cl})(\mu-\mathrm{Cl})\right]_{2}(0.400 \mathrm{~g}, 0.653 \mathrm{mmol})$ and $\mathrm{PPh}_{3}(0.360 \mathrm{~g}, 1.37 \mathrm{mmol})$ were stirred at room temperature for $2 \mathrm{~h}$ in $\mathrm{CH}_{2} \mathrm{Cl}_{2}$ ( $15 \mathrm{~mL}$ ), after which time the solution was reduced in vacuo to $3 \mathrm{~mL}$. Hexanes were added to yield an orange precipitate. The mixture was filtered through a fine porosity frit. The solid was washed with pentane and dried in vacuo to yield an orange solid $(0.658 \mathrm{~g}, 88.7 \%$ yield $) .{ }^{1} \mathrm{H}$ NMR spectroscopy revealed clean material and was consistent with previously reported data. ${ }^{47} \mathrm{CV}\left(\mathrm{NCCH}_{3}\right)$ : $E_{1 / 2}=1.25 \mathrm{~V} \mathrm{Ru}($ III $/$ II $) ; E_{\mathrm{p}, \mathrm{c}}=1.25 \mathrm{~V}$.

General Procedure for the Measurement of Rates of Exchange. Stock solutions in $\mathrm{CDCl}_{3}$ were prepared in a volumetric flask. Each kinetic experiment was performed in triplicate. For each experiment, $\mathrm{CDCl}_{3}$ solutions of $\mathrm{P}(\mathrm{OMe})_{3}$ and /or $\mathrm{PPh}_{3}$ were combined in a screw cap NMR tube with $\mathrm{CDCl}_{3}$ such that the reaction volume before addition of $\mathrm{Ru}$ complex totaled $0.40 \mathrm{~mL}$. Immediately before placing the solution into the NMR probe (equilibrated at $58 \mathrm{C}), 0.20 \mathrm{~mL}$ of the Ru complex $(12,13$, or 15$)$ (with hexamethyldisiloxane as an internal standard) was added by syringe to give a total volume $0.60 \mathrm{~mL}$. The tube was inverted two times. Reaction progress was monitored by ${ }^{1} \mathrm{H}$ NMR spectroscopy using automated data acquisition. A single transient was used for each time point with $60 \mathrm{~s}$ delay between transients for reactions with solutions of 13 and 15 , and a $600 \mathrm{~s}$ between transients for reactions of complex 12. The rate of the reaction was determined by monitoring the disappearance of starting material [complex 12: $4.37 \mathrm{ppm}\left[\mathrm{d},{ }^{3}\right]_{\mathrm{HP}}=5.0 \mathrm{~Hz}$, $\left.\mathrm{P}\left(\mathrm{OCH}_{2}\right)_{3} \mathrm{CCH}_{2} \mathrm{CH}_{3}\right]$; complex 15: $1.87 \mathrm{ppm}\left[\mathrm{s}\right.$, (p-cymene) $\mathrm{C}_{6} \mathrm{H}_{4}$

$\left.\mathrm{CH}_{3}\right]$, and complex 13: $1.68 \mathrm{ppm}\left[\mathrm{s}, 3 \mathrm{H}, \mathrm{P}\left(\mathrm{OCH}_{2}\right)_{2}\left(\mathrm{OCCH}_{3}\right)\right]$. Each 
reaction was monitored through at least 3.5 half-lives. Rates were determined by least-squares analyses of a plot of starting material vs time (seconds).

\section{ASSOCIATED CONTENT}

\section{(5) Supporting Information}

Crystallographic data in CIF format. Further details are given in Figures S1 S9 and Tables S1 S3. This material is available free of charge via the Internet at http://pubs.acs.org.

\section{AUTHOR INFORMATION}

\section{Corresponding Author}

${ }^{\star}$ E-mail: tbg7h@virginia.edu (T.B.G.).

\section{Notes}

The authors declare no competing financial interest.

\section{ACKNOWLEDGMENTS}

We acknowledge the Office of Basic Energy Sciences, U.S. Department of Energy, for support of this work [DESC0000776 (T.B.G.) and DE-FG02-03ER15387 (T.R.C.)] and the NSF (CHE-0320669) for financial support of instrumentation at the University of Richmond. We also thank Ms. Diana A. Iovan for assistance with acquisition of mass spec data.

\section{REFERENCES}

(1) Crabtree, R. H. The Organometallic Chemistry of the Transition Metals, 4th ed.; Wiley-Interscience: Hoboken, NJ, 2005; pp 99103.

(2) Keiter, R. L.; Verkade, J. G. Inorg. Chem. 1970, 9, 404406.

(3) Verkade, J. G.; McCarley, D. G.; Hendricker, D. G.; King, R. W. Inorg. Chem. 1965, 4, 228231.

(4) Meiners, J. H.; Rix, C. J.; Clardy, J. C.; Verkade, J. G. Inorg. Chem. 1975, 14, 705710 .

(5) Serron, S.; Nolan, S. P.; Abramov, Y. A.; Brammer, L.; Petersen, J. L. Organometallics 1998, 17, 104110.

(6) Tolman, C. A. Chem. Rev. 1977, 77, 313348.

(7) Freixa, Z.; van Leeuwen, P. W. N. M. Dalton Trans. 2003, 1890 1901.

(8) Bunten, K. A.; Chen, L.; Fernandez, A. L.; Poe, A. J. Coord. Chem. Rev. 2002, 233 234, 4151.

(9) Leyssens, T.; Peeters, D.; Orpen, A. G.; Harvey, J. N. Organometallics 2007, 26, 26372645.

(10) Downing, J. H.; Smith, M. B. In Comprehensive Coordination Chemistry II; Elsevier: Amsterdam, The Netherlands, 2004; Vol. 1, pp 253296.

(11) Kuehl, O. Coord. Chem. Rev. 2005, 249, 693704.

(12) Sasaki, S.; Yoshifuji, M. Curr. Org. Chem. 2007, 11, 1731.

(13) van Leeuwen, P. W. N. M.; Freixa, Z.; Zuidema, E. Phosphorus Ligands in Asymmetric Catalysis; Wiley-VCH: Weinheim, Germany, 2008; Vol. 3, pp 14331454.

(14) Muller, T. E.; Mingos, D. M. P. Transition Met. Chem. 1995, 20, 553539.

(15) Gilheany, D. G. Structure and bonding in organophosphorus(III) compounds. In The Chemistry of Organophosphorus Compounds; Hartley, F. R., Ed.; John Wiley \& Sons: New York, 1990; Vol. 1, pp 949.

(16) Valentine, D. H.; Hillhouse, J. H. Synthesis 2003, 24372460.

(17) Meiners, J. H.; Clardy, J. C.; Verkade, J. G. Inorg. Chem. 1975, 14, 632636 .

(18) Hartwig, J. F. Organotransition Metal Chemisty: from Bonding to Catalysis. University Science Books: Herndon, VA, 2010; p 3238.

(19) Valentine, D. H.; Hillhouse, J. H. Synthesis 2003, 317334.

(20) Kuehl, O. Can. J. Chem. 2007, 85, 230238.

(21) Cao, M.; Do, L. V.; Hoffman, N. W.; Kwan, M. L.; Little, J. K.; McGilvray, J. M.; Morris, C. B.; Soderberg, B. C.; Wierzbicki, A.;
Cundari, T. R.; Lake, C. H.; Valente, E. J. Organometallics 2001, 20, 22702279.

(22) Fortman, G. C.; Nolan, S. P. Organometallics 2010, 29, 4579 4583.

(23) Verkade, J. G.; Hutteman, T. J.; Fung, M. K.; King, R. W. Inorg. Chem. 1965, 4, 8387.

(24) Heitsch, C. W.; Verkade, J. G. Inorg. Chem. 1962, 1, 392398.

(25) Rix, C. J.; Verkade, J. G. Coord. Chem. Rev. 1975, 16, 129139.

(26) Verkade, J. G. Bioinorg. Chem. 1974, 3, 165182.

(27) Vande Griend, L. J.; Verkade, J. G.; Pennings, J. F. M.; Buck, H. M. J. Am. Chem. Soc. 1977, 99, 24592463.

(28) Verkade, J. G. Coord. Chem. Rev. 1972, 9, 1106.

(29) Milbrath, D. S.; Springer, J. P.; Clardy, J. C.; Verkade, J. G. J. Am. Chem. Soc. 1976, 98, 54935496.

(30) Huttemann, T. J.; Foxman, B. M.; Sperati, C. R.; Verkade, J. G. Inorg. Chem. 1965, 950.

(31) Foley, N. A.; Ke, Z. F.; Gunnoe, T. B.; Cundari, T. R.; Petersen, J. L. Organometallics 2008, 27, 30073017.

(32) Verkade, J. G.; Piper, T. S. Inorg. Chem. 1963, 2, 944947.

(33) Denny, D. B.; Varga, S. L. Phosphorus 1973, 2, 245248.

(34) Nifantyev, E. E.; Koroteev, A. M.; Koroteev, M. P.; Meshkov, S. V.; Belsky, V. K.; Bekker, A. R. Phosphorus, Sulfur Silicon Relat. Elem. 1996, 113, 113 .

(35) Wadsworth, W. S.; Emmons, W. D. J. Am. Chem. Soc. 1962, 610617.

(36) Wirz, B.; Barner, R.; Hubscher, J. J. Org. Chem. 1993, 58, 3980 3984.

(37) Roebuck, A.; Adkins, H. A. Organic Synthesis; John Wiley \& Sons, Inc.: New York, 1955; Vol. 3.

(38) Slugovc, C.; Sapunov, V. N.; Wiede, P.; Mereiter, K.; Schmid, R.; Kirchner, K. J. Chem. Soc, Dalton Trans. 1997, 42094216.

(39) Werner, H.; Brauers, G.; Nurnberg, O. J. Organomet. Chem. 1993, 454, 247255.

(40) Zelonka, R. A.; Baird, M. C. Can. J. Chem. 1972, 50, 30633072.

(41) Bennett, M. A.; Smith, A. K. J. Chem. Soc., Dalton Trans. 1974, 233241.

(42) Werner, H.; Werner, R. Chem. Ber-Recl. 1982, 115, 37663780.

(43) Zelonka, R. A.; Baird, M. C. J. Organomet. Chem. 1972, 35, C43 C46.

(44) Elsegood, M. R. J.; Tocher, D. A. Polyhedron 1995, 14, 3147 3156.

(45) Pigge, F. C.; Coniglio, J. J. Curr. Org. Chem. 2001, 5, 757784. (46) Bard, A. J.; Faulkner, L. R. Electrochemical Methods: Fundamentals and Applications, 2nd ed.; John Wiley \& Sons: New York, 2001; p 231.

(47) Hodson, E; Simpson, S. J. Polyhedron 2004, 23, 26952707.

(48) Furstner, A.; Liebl, M.; Lehmann, C. W.; Picquet, M.; Kunz, R.; Bruneau, C.; Touchard, D.; Dixneuf, P. H. Chem. Eur. J. 2000, 6, 18471857.

(49) Elsegood, M. R. J.; Smith, M. B.; Sanchez-Ballester, N. M. Acta Crystallogr., Sect. E 2006, 62, M2838 M2840.

(50) Orpen, A. G.; Connelly, N. G. J. Chem. Soc., Chem. Commun. 1985, 13101311.

(51) Dias, P. B.; Depiedade, M. E. M.; Simoes, J. A. M. Coord. Chem. Rev. 1994, 135, 737807.

(52) Jover, J.; Fey, N.; Harvey, J. N.; Lloyd-Jones, G. C.; Orpen, A. G.; Owen-Smith, G. J. J.; Murray, P.; Hose, D. R. J.; Osborne, R.; Purdie, M. Organometallics 2010, 29, 62456258.

(53) Ellis, D. D.; Haddow, M. F.; Orpen, A. G.; Watson, P. J. Dalton Trans. 2009, 1043610445.

(54) Taira, K.; Mock, W. L.; Gorenstein, D. G. J. Am. Chem. Soc. 1984, 106, 78317835 .

(55) Belyakov, A. V.; Dalhus, B.; Haaland, A.; Shorokhov, D. J.; Volden, H. V. J. Chem. Soc., Dalton Trans. 2002, 37563762.

(56) Slater, J. C. Quantum Theory of Molecules and Solids; McGrawHill: New York, 1974; Vol. 4, The Self-Consistent Field for Molecules and Solids.

(57) Becke, A. D. Phys. Rev. A 1988, 38, 30983100.

(58) Perdew, J. P. Phys. Rev. B 1986, 34, 74067406. 
(59) Perdew, J. P. Phys. Rev. B 1986, 33, 88228824.

(60) Perdew, J. P.; Zunger, A. Phys. Rev. B 1981, 23, 50485079.

(61) Hay, P. J.; Wadt, W. R. J. Chem. Phys. 1985, 82, 270283.

(62) Pyykko, P.; Mendizabal, F. Inorg. Chem. 1998, 37, 30183025.

(63) Couty, M.; Hall, M. B. J. Comput. Chem. 1996, 17, 13591370.

(64) Frisch, M.J.; Trucks, G. W.; Schlegel, H. B.; Scuseria, G. E.; Robb, M. A.; Cheeseman, J. R.; Scalmani, G.; Barone, B. M.; Petersson, G. A.; Nakatsuji, H.; Caricato, M.; Li, X.; Hratchian, H. P.; Izmaylov, A. F.; Bloino, J.; Zheng, G.; Sonnenberg, J. L.; Hada, M.; Ehara, M.; Toyota, K.; Fukuda, R.; Hasegawa, J.; Ishida, T. N.; Honda, Y.; Kitao, O.; Nakai, H.; Vreven, T.; Montgomery, J.A.; Jr.; Peralta, J. E.; Ogliaro, M. B.; Heyd, J. J.; Brothers, E.; Kudin, K. N.; Staroverov, V. N.; Kobayashi, R.; Normand, K. R.; Rendell, A.; Burant, J. C.; Iyengar, S. S.; Tomasi, J.; Cossi, M.; Rega, N.; Millam, J. M.; Knox, J. E.; Cross, J. B.; Bakken, V.; Adamo, C.; Jaramillo, J.; Gomperts, R.; Stratmann, R. E.; Austin, A. J.; Cammi, R.; Pomelli, C.; Ochterski, J. W.; Martin, R. L.; Morokuma, K.; Zakrzewski, V. G.; Voth, G.; Salvador, P.; Dannenberg, J. J.; Dapprich, S.; Daniels, A.D.; Farkas, O.; Foresman, J. B.; Cioslowski, J.; Fox., D. J. Gaussian 09, Revision A.1; Gaussian, Inc.: Wallingford, CT, 2009. 